\title{
THE ARCHAEOLOGY OF THE SOUTHERN CURTIS COAST: AN OVERVIEW
}

\author{
SEAN ULM AND IAN LILLEY \\ Aboriginal and Torres Strait Islander Studies Unit, University of Queensland, \\ Brisbane, Queensland, 4072, Australia
}

\begin{abstract}
Since 1993 archaeological surveys and excavations have been undertaken on the southern Curtis Coast as the coastal component of the Gooreng Gooreng Cultural Heritage Project. This paper briefly outlines the physical environment of the study region including geology, vegetation and fauna communities before presenting the preliminary results of archaeological surveys and excavations. These initial results suggest that the region has an extensive mid-to-late Holocene archaeological record that has the potential to contribute to understandings of changes in late Holocene Aboriginal societies in Central Queensland.
\end{abstract}

\section{Introduction}

The southern Curtis Coast area was selected as a coastal focus for Gooreng Gooreng Cultural Heritage Project preliminary archaeological investigations for five main reasons: (1) previous studies (Burke 1993; Godwin 1990; Rowland 1987) had indicated the considerable archaeological potential of the region; (2) the region included a variety of coastal zones such as open beaches, estuaries and embayments not typical of the coast to the immediate south or north; (3) until recently the region has not been subject to any major coastal landscape-altering development, suggesting the probability of low-level site disturbance; (4) the area includes a high concentration of National Parks and other protected areas facilitating access; and, (5) the general region is recognised as a prime area for heavy industrial, residential and tourist growth where cultural heritage data are urgently required for the development of effective management plans (Lilley and Ulm 1995).

\section{Physical Setting}

The southern Curtis Coast study area is located on the central coast of Queensland, just south of the Tropic of Capricorn. The study area extends from Wreck Rock in the Deepwater Section of Eurimbula National Park in the south to Richards Point in the Rodds Peninsula Section of Eurimbula National Park in the north and from the coast to Miriam Vale and Seven Mile Creek in the west (Figure 1). The study region covers a total land area of about $1,200 \mathrm{~km}^{2}$, with a high water level shoreline length of approximately $450 \mathrm{~km}$. The study area is located c. $70 \mathrm{~km}$ northwest of Bundaberg and c. $20 \mathrm{~km}$ southeast of Gladstone, between latitudes $24^{\circ} 20^{\prime}$ and $23^{\circ} 58^{\prime}$ south and longitudes $151^{\circ} 30^{\prime}$ and $151^{\circ} 57^{\prime}$ east.

\section{Geology and Geomorphology}

The southern Curtis Coast comprises a relatively restricted range of rock types and landforms dating from the Triassic period of more than 160 million years ago, to the very much more recent estaurine and beach ridge deposits dating to the last 6,000 years (QDEH 1994:33). The basal geology of all but the extreme west of the study area is dominated by rhyolites and granites assigned to the Agnes Water Volcanics formation of the Toogoolawah Group dating to 235-213 million years ago (Ellis and Whitaker 1976; Stevens 1968). Bustard Head and Rodds Peninsula are composed of unnamed granites of Triassic age. Although the region is punctuated by rocky headlands, the study area is characterised as a depositional coastline with low north-northwest trending Holocene beach ridges and swales oriented roughly parallel to the modern coastline, trailing northwards from the northern side of almost every estuary of note (Hopley 1985:76-77). Beach ridges and sand masses consist of fine-grained quartz sands and dispersed heavy mineral sands including rutile, ilmenite and zircon (Connah 1961).

The coast in the study area is open to full oceanic conditions, which has significantly impacted upon coastal sedimentation and erosion regimes. This situation is relatively unusual on the Queensland coast, as to the south (with the exception of Cooloola) the mainland coast is protected by Fraser, Moreton, and North and South Stradbroke Islands, and to the north by the Great Barrier Reef.

One of the primary issues in evaluating the regional archaeological record is consideration of palaeoenvironmental factors, particularly the potential effects of sea-level change and erosion on site survival and visibility. Accumulating geomorphological evidence suggests that there may have been minor variations in sea-level along the eastern Australian coast since 6,000 BP. Larcombe et al. (1995) have recently presented a model of episodic post-glacial sea-level rise based on a detailed study of radiocarbon dates from the central Great Barrier Reef shelf (between Hayman Island and Cape Tribulation) for the last c.12,000 years. On this basis, they identify a peak in sea-level at c.8,500 BP at 
c. $-11 \mathrm{~m}$, a regression at c. $8,200 \mathrm{BP}$ at $-17 \mathrm{~m}$, followed by a rapid rise to c. $-5 \mathrm{~m}$ at c. 7,800 BP. Sea-level remained relatively stable until c.6,800 BP before a rise to a short stillstand at $-2 \mathrm{~m}$ at c.6,000 $\mathrm{BP}$ and then to the Holocene stillstand of $+1.65 \mathrm{~m}$ at c.5,500 BP until c. $3,700 \mathrm{BP}$, when sea-levels dropped to approximately modern values. This model contrasts with earlier sea-level curves for northeastern Australia, which have suggested stabilization at current levels at 6,000 $\pm 500 \mathrm{BP}$ (e.g. Belperio 1979; Hopley 1983; Lambeck and Nakada 1990; Thom and Roy 1983).

This model of sea-level change has significant ramifications for understanding the archaeology of the study area, as much of the land within $2 \mathrm{~km}$ of the present coastline exhibits very low elevation, interspersed with large freshwater swamps and wetlands and extensive estuarine systems. Field surveys and examination of aerial photographs revealed a regular system of parallel transgressive beach ridges extending over much of the study area (particularly between Round Hill and Falls Creeks), suggesting major transformations of the coastal landscape over time. The assignment of the majority of these changes to the late Holocene is supported by a preliminary series of four radiocarbon dates from a pollen core taken from freshwater wetlands adjoining Round Hill Creek (on the inland side of a major series of transgressive beach ridges), suggesting a basal date for swamp formation of c.3,000 years ago, consistent with recent arguments for sea-level retreat (M. Cotter, Centre for Coastal Management, Southern Cross University, pers. comm., 1999).

Taken together, this evidence suggests a very recent origin for many of the coastal landforms which are the subject of this study, including numerous tidal estuaries, extensive inter-tidal and sub-tidal mudflats, low sandy beach ridges and cheniers (Figures 2-6).

\section{Climate}

The region has a sub-tropical, maritime climate influenced by the southeast trade winds, regional topography and the moderating influences of the ocean. The region experiences occasional monsoon influences, although cyclones are more frequent features, as are the major frontal systems common in more southerly latitudes. These varied influences generate marked variability in rainfall, temperature and prevailing wind conditions on the Curtis Coast (QDEH 1994:11).

The average maximum and minimum temperatures in the region range from $28.9^{\circ} \mathrm{C}$ and $22.8^{\circ} \mathrm{C}$ respectively in the summer to $20.9^{\circ} \mathrm{C}$ and $13.4^{\circ} \mathrm{C}$ respectively in the winter (QDEH 1994:13). Regional rainfall is summer-dominated, with January and February commonly the wettest months and August and September the driest, with mean annual rainfall at the Town of Seventeen Seventy of $1,318 \mathrm{~mm}$ (QDEH 1994:11). Major factors which influence the distribution of rainfall include topographic influences of mountain ranges, geographic influences such as the orientation of the coastline to the prevailing watersaturated winds, and occasional cyclones causing extreme rain events from November to April.

\section{Hydrology}

The Curtis Coast is transected by numerous creeks and rivers which form an extensive network of interconnected estuaries. Numerous minor seasonal tributaries drain into estuarine creeks from the low sub-coastal ranges in the west. The Munro Range, Edinburgh Mountains and Westwood Range divide the catchments of Baffle, Round Hill, Eurimbula and Middle Creeks to the south and east from Worthington and Seven Mile Creeks to the north (Olsen 1980a:4). The major influences on water movement within these tributaries are prevailing tides and weather conditions, although freshwater inflow associated with periods of high intensity rainfall can cause heavy runoff, which produces short-term fluctuations in estuary salinity and turbidity (Olsen 1980a:5). Olsen (1980a:6) notes that tidal flushing of estuaries is generally high, except for a period of depressed salinity between January and March suggesting significant terrestrial freshwater rainfall input (see also Lupton and Heidenreich 1996 for similar data for Baffle Creek).

In the south, Round Hill, Eurimbula, Middle and Pancake Creeks are generally shallow, mangrovefringed estuaries characterised by sandy bottoms merging to silt and clay in the upper reaches (Olsen 1980a:3). To the north, Rodds Harbour and Seven Mile Creek exhibit deeper channels near the mouth and extensive flats and zones of silty sand upstream with large areas of mangroves with clay pans bordering grassy or layered eucalypt forest (Olsen 1980a:3).

Tidal processes of the Curtis Coast are influenced by the presence of the southern extremities of the Great Barrier Reef, ocean floor topography and coastal geology, such as inshore islands and headlands (QDEH 1994:17). The tidal effects of estuaries also contribute to the amplification of tidal range along the Curtis Coast, with an average maximum tidal range of $2.43 \mathrm{~m}$ at Pancake Creek in the approximate centre of the study region (QDOT 1998). Like all coastal regions, the area is subject to both wind- and storm-generated waves which modify the configuration of the shoreline. Unfortunately, only scant research into coastal erosion processes has been undertaken in the area and the effects of erosion on the representation of archaeological materials in 


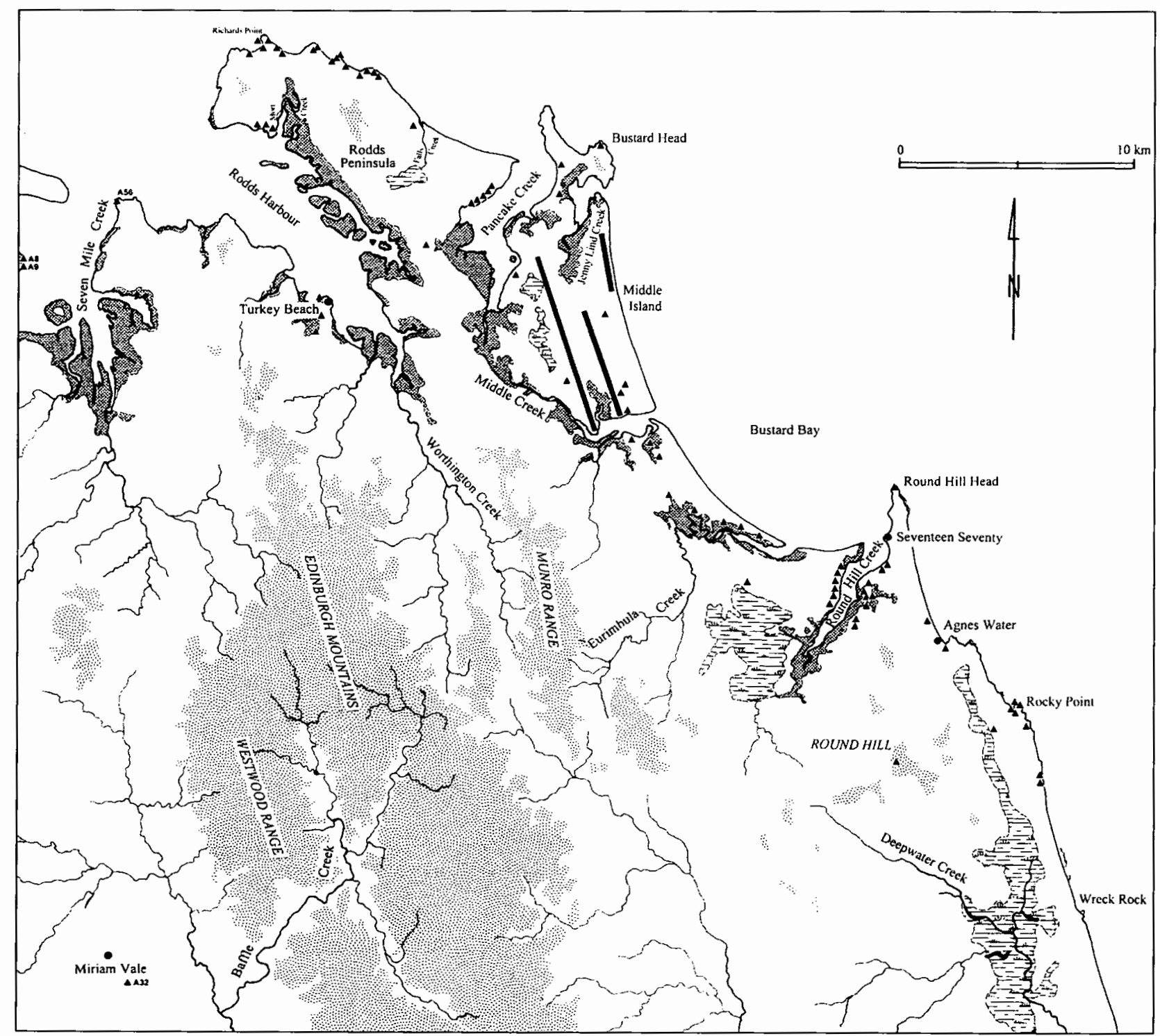

Figure 1. The southern Curtis Coast study area, showing all recorded archaeological sites as triangles (after Burke 1993; Davies 1994; Lilley 1994; Lilley et al. 1997; Neal 1986; Rowland 1987; Ulm 1999). Site designations are shown for sites which are not illustrated in Figures 8-9. These sites are listed in Appendix A with the prefix 'KE:'. 
open beach contexts is difficult to assess. Anecdotal evidence and field observations suggest that stormsurge activity exacerbates local erosion (Figure 7).

\section{Vegetation}

The ecological complexity and diversity of the study region reflects its status as part of a transitional zone between tropical and temperate provinces, with a zoogeographical boundary identified at about latitude $25^{\circ}$ south (Endean et al. 1956; Knox 1963). This overlap generally translates into high rates of floral and faunal diversity, with representation of both tropical and temperate species. The region supports an extensive range of herblands, grasslands, heaths, scrubs and tall shrublands, and open and closed forests (QDEH 1994:45). Mixed herblands on foredunes include Ipomoea pes-caprae and Canavalia rosea. Extensive wet and dry heathlands occur on poorly-drained sandy-loam soils, comprising a number of species generally less than $2 \mathrm{~m}$ in height, including banksia (Banksia sp.), paperbark (Melaleuca sp.), and grass trees (Xanthorrhoea sp.). Beach ridges support tall open paperbark forests, dominated by the species Melaleuca leucadendra and $M$. dealbata in association with cabbage-tree palm communities (Livistona australis) (QDEH 1994:48). The distribution of closed forest is limited, with a relatively restricted tall, araucarian closed-forest community found bordering Eurimbula Creek, with hoop pine Araucaria cunninghamii emergent above a notophyll vine forest (QDEH 1994:49).

Estuary systems exhibit extensive fringing vegetation communities consisting of combinations of some 13 mangrove species dominated by the grey mangrove (Avicennia marina), red mangrove (Rhizophora stylosa) and yellow mangrove (Ceriops tagal) (Dowling 1980; Olsen 1980a). Seagrass beds (dominated by Zostera capricornia) are typically found in sheltered waters where water clarity allows sufficient light penetration for photosynthesis, including Round Hill Creek, Rodds Harbour, Pancake Creek and Mort Creek (Olsen 1980b; QDEH 1994). These habitats provide important breeding and feeding grounds for prawns, crabs and fish as well as turtles, dugongs and numerous water fowl.

\section{Fauna}

The region's terrestrial fauna is diverse and includes 60 species of mammals (including bats, echidna, koala and kangaroos), 59 species of reptiles (including lizards and snakes) and 288 bird species (including shorebirds, waterbirds, seabirds and birds of prey) (QDEH 1994:59-65). Macropods include the eastern grey kangaroo (Macropus giganteus), whiptail wallaby $(M$. parryi) and swamp wallaby (Wallabia bicolor). Occasional dingoes (Canis familiaris) have also been sighted in remote parts of the study region. Bird species common to these habitats include the beach thick-knee (Esacus magnirostris) and eastern curlew (Numenius madagascariensis). The terrestrial environment has been impacted by intensive logging of local areas and long-term grazing of cattle. At least one local extinction is apparent, that of the eastern bustard or plain turkey (Choriotis australis) (Growcott and Taylor 1996:25).

Common marine fauna found along the Curtis Coast include a number of whale species (including the humpback Megaptera novaeangliae), four species of dolphin, dugongs (Dugong dugong) and turtles (including loggerhead Carreta caretta and green Chelonia mydas). Rodds Harbour supports the largest dugong population along the Curtis Coast (QDEH 1994:66). As a transition zone, the area is also a wintering destination for some whales and migratory waterbirds.

A total of 148 species of fishes from 69 families is recorded for the Curtis Coast (QDEH 1994:68). A detailed study of the lower estuarine sections of Baffle Creek just to the south of the study area conducted in 1993-1994 by Lupton and Heidenreich (1996) provides useful data. The lower estuarine component of this fisheries resource assessment covered habitats similar to the coastal estuaries in the study area. Despite significantly depressed regional rainfall levels ( $25 \%$ under the annual average) before and during the survey period, 55 fish and nine crustacean species were recorded. The larger fish species were dominated (in order of abundance) by flat-tail mullet (Liza dussumieri), sand mullet (Myxus elongatus), whiting (Sillago ciliata, S. maculata and S. sihama), bream (Acanthopagrus australis), bluetail mullet (Valamugil seheli), sea mullet (Mugil cephalus) and garfish (including Arrhamphus sclerolepis and Hyporhamphus ardelio) (Grant 1993; Lupton and Heindenreich 1996). Commercial finfish catches for the region similarly reflect this pattern, with mullet, whiting and bream accounting for $64.1 \%$ of commercial catches (Olsen 1980a:11). Mud crabs (Scylla serrata) and sand crabs (Portunus pelagicus) are also common.

The contemporary estuarine molluscan fauna along the southern Curtis Coast is dominated by commercial oyster (Saccostrea commercialis), found in mangrove and rocky habitats, and gastropods such as hercules club shell (Pyrazus ebeninus), and members of the family Potamididae, including the mud creepers Telescopium telescopium and Terebralia sulcata (Roughley 1928; Shanco and Timmins 1975). Midden deposits are dominated by commercial oyster and the mud ark Anadara trapezia, an estuarine bivalve, although this species is very 


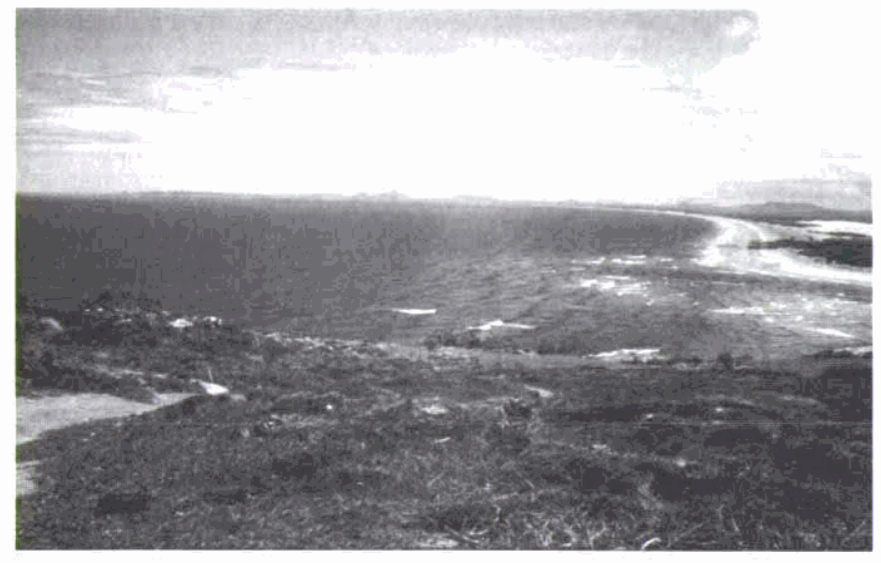

Figure 2. General view of Bustard Bay, showing the mouth of Jenny Lind Creek in foreground, facing southeast (Photograph: S. Ulm).

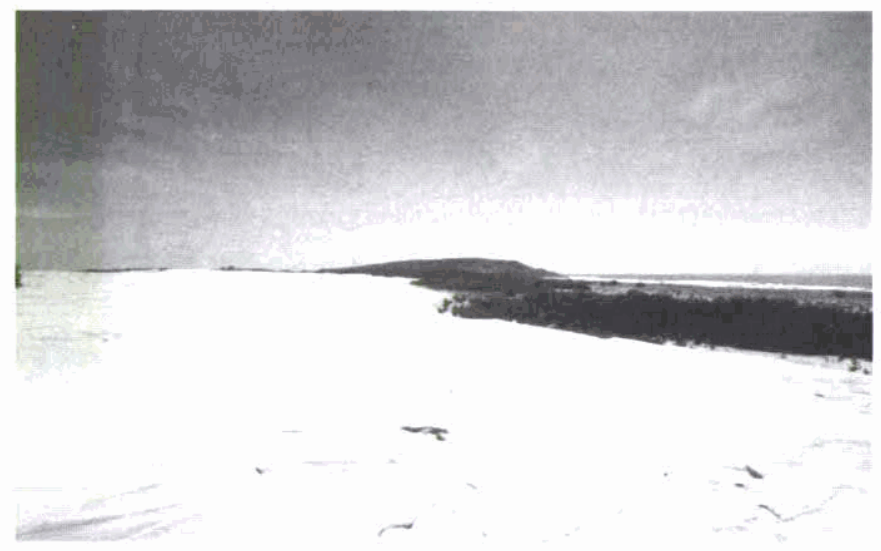

Figure 4. High sandmass on northeast Middle Island, showing Bustard Head in background, facing north (Photograph: S. UIm).

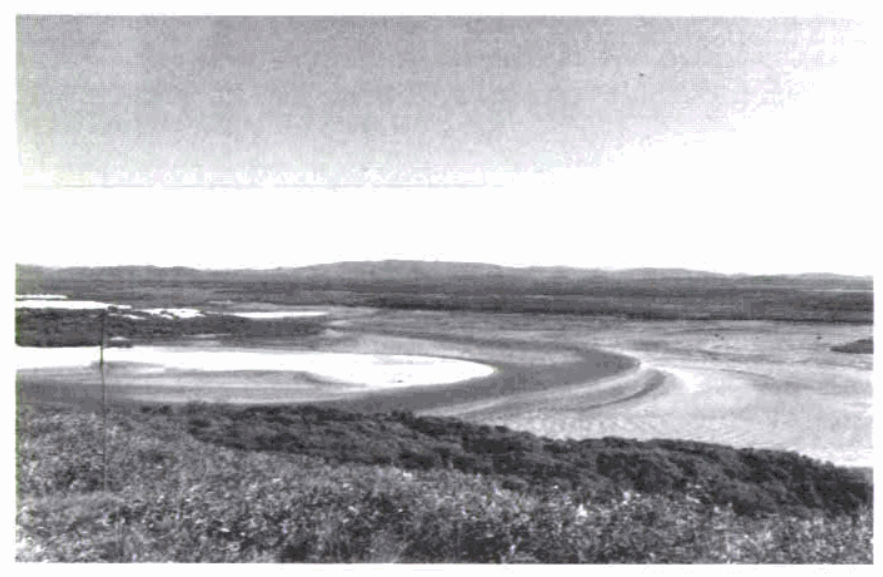

Figure 6. General view of estuary systems and near-coastal ranges across Jenny Lind Creek, facing southwest (Photograph: S. Ulm).

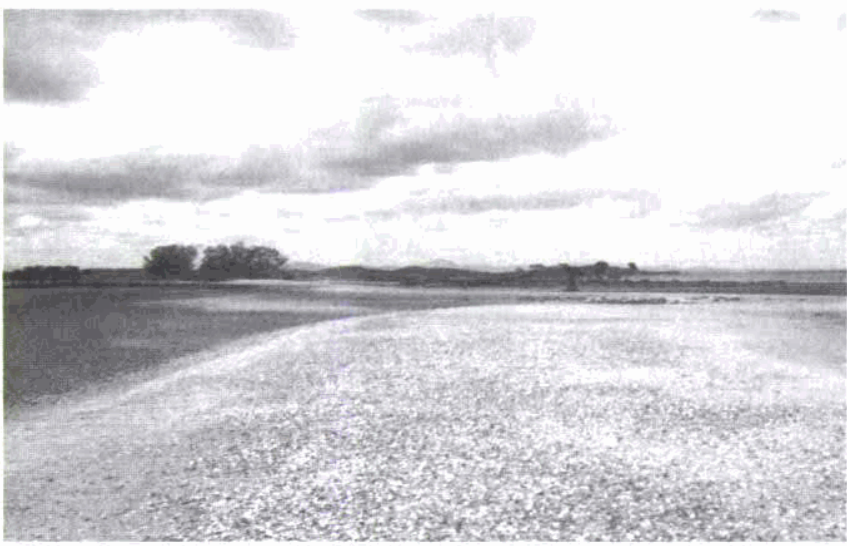

Figure 3. Chenier ridge on Rodds Peninsula extending into Rodds Harbour, facing southwest (Photograph: I. Lilley).

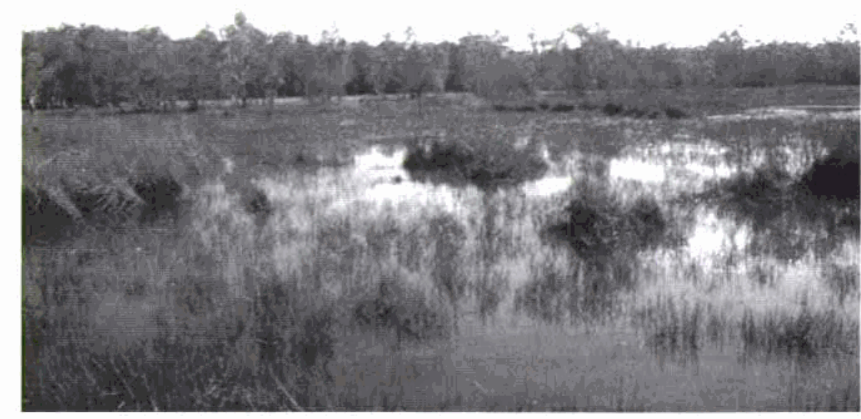

Figure 5. Freshwater wetlands adjoining the upper reaches of Round Hill Creek, facing north (Photograph: S. UIm).

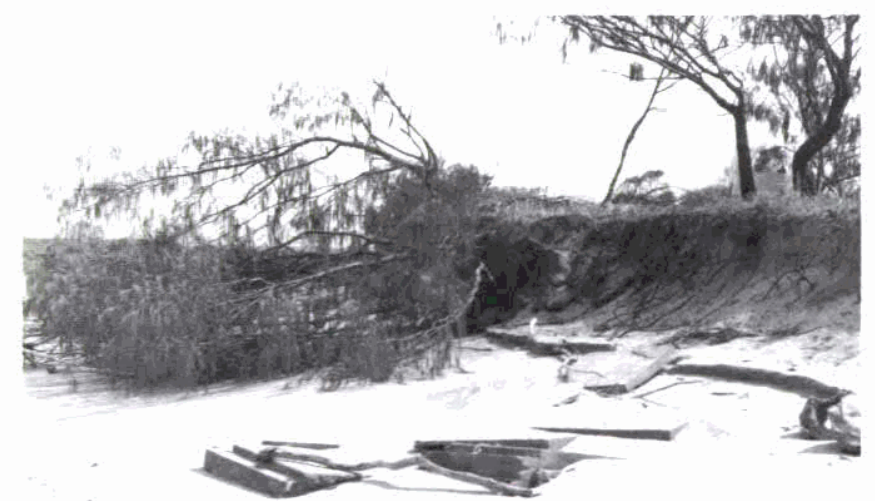

Figure 7. Creek bank erosion, north bank of Middle creek, facing northwest (Photograph: S. Ulm). 
sparse in the coastal waters of Queensland today (Chappell and Grindrod 1984:222) and is not included in estuarine inventories for the region (Shanco and Timmins 1975). Contemporary open coast molluscs are relatively depauperate, with scattered populations of milky oyster (Saccostrea amassa) on exposed rocky headlands (Olsen 1980a:11,13) and pipi (Donax deltoides) on stretches of sandy coast.

\section{Cultural Setting}

The ethnohistoric record for the Curtis Coast is generally very sparse, with considerable conflict both among documentary sources and between documentary and Aboriginal oral histories (see Clarkson et al. in prep for a detailed discussion). In one of the earliest discussions of Aboriginal lifeways in this area, Curr $(1887: 122,126)$ used the term 'Maroonee' to describe the people occupying the coastal areas of Rodds and Bustard Bays and inland to the Many Peaks Range. Mathew (1914) also placed 'Meerooni' in this area. Brasch (1975) suggested that a dialect of Gooreng Gooreng labelled 'Guweng' occurred in this same geographical area. Tindale (1974) termed this group 'Goeng' (also listing Meerooni, Gurang Gurang and Yungkong), and suggested it covered an area from Miriam Vale and south to the mouth of Baffle Creek. Significantly, Williams (1981:62) was not certain about including the area fringing Bustard Bay within Gooreng Gooreng country, despite extensive interviews with Aboriginal people from the study area. Clarkson et al. (in prep.) suggest that as the various terms refer to country today identified with Gooreng Gooreng speakers (see also Curr's 1887 language list for the Meerooni of Baffle Creek where 'no'= 'Gooraong'), they are unlikely to refer to the name of a language per se, but may be that of a dialect group or subgroup of Gooreng Gooreng (Burke 1993:8). In contemporary discourses, the study area is considered to be broadly part of the country of Gooreng Gooreng people (Clarkson et al. in prep.).

The very few documentary sources which relate to the immediate southern Curtis Coast study area span from Bank's observation on 23 May 1770 of two Aboriginal men walking along the beach just south of Bustard Bay (Beaglehole 1963:65). The following day, a party from the Endeavour went ashore at Bustard Bay to inspect the country, noting "innumerable Oysters, Hammer oysters and many more sorts" and a recently-vacated occupation site:

Those who stayd on board the ship saw about 20 of the natives, who came down abreast of the ship and stood upon the beach for some time looking at her, after which they went into the woods; we on shore saw none. Many large fires were made at a distance from us where probably the people were. One small one was in our neighbourhood, to this we went; it was burning when we came to it, but the people were gone; near it was left several vessels of bark which we conceivd were intended for water buckets, several shells and fish bones, the remainder I suppose of their last meal. Near the fires, for there were 6 or 7 small ones, were as many peices of soft bark of about the length and breadth of a man: these we supposd to be their beds: on the windward side of the fires was a small shade about a foot high made of bark likewise. The whole was in a thicket of close trees, defended by them from the wind; whether it was realy or not the place of their abode we can only guess. We saw no signs of a house or any thing like the ruins of an old one, and from the ground being much trod we concluded that they had for some time remaind in that place (Beaglehole 1963:67).

Other members of the landing party also reported the tail of a land animal at the camp to those that remained on the ship (Pickersgill in Bladen 1892:218).

Subsequent sources (mainly from ships and exploratory vessels) make passing references to sightings of Aboriginal people, material culture or smoke from campfires in the general region (e.g. Flinders 1814; Oxley 1825). Flinders (1814:15-16) in August 1802 noted bark canoes, turtle remains and scoop nets at the southern end of Curtis Island to the north. In 1846, MacGillivray (1852:57) made the following observations while visiting Port Curtis:

During our stay at Port Curtis, we had no intercourse whatever with the natives, although anxious to establish friendly communication. With the aid of the spyglass, we could occasionally make out a few, chiefly women, collecting shell-fish on the mud flats of the main land, and their fires were daily seen in every direction.

Although there have been suggestions of patterns of coastal transhumance related to water shortages (e.g. Oxley 1825), early historical sources document the presence of Aboriginal populations on the coast throughout the year (Burke 1993; Clarkson et al. in prep.) and permanent water stored in coastal sandmasses appears to have been perennially available (Buchanan 1999).

The most recent ethnohistoric documentary account for the immediate study area is from October 1846, when Colonel George Barney on board the Cornubia encountered Aborigines close to their camp while searching the southern entrance of Bustard Bay for freshwater with which to fill the ship's casks. Barney was shown a small freshwater soak in dense scrub about 100m from the base of Round Hill Head (McDonald 1988:10). 


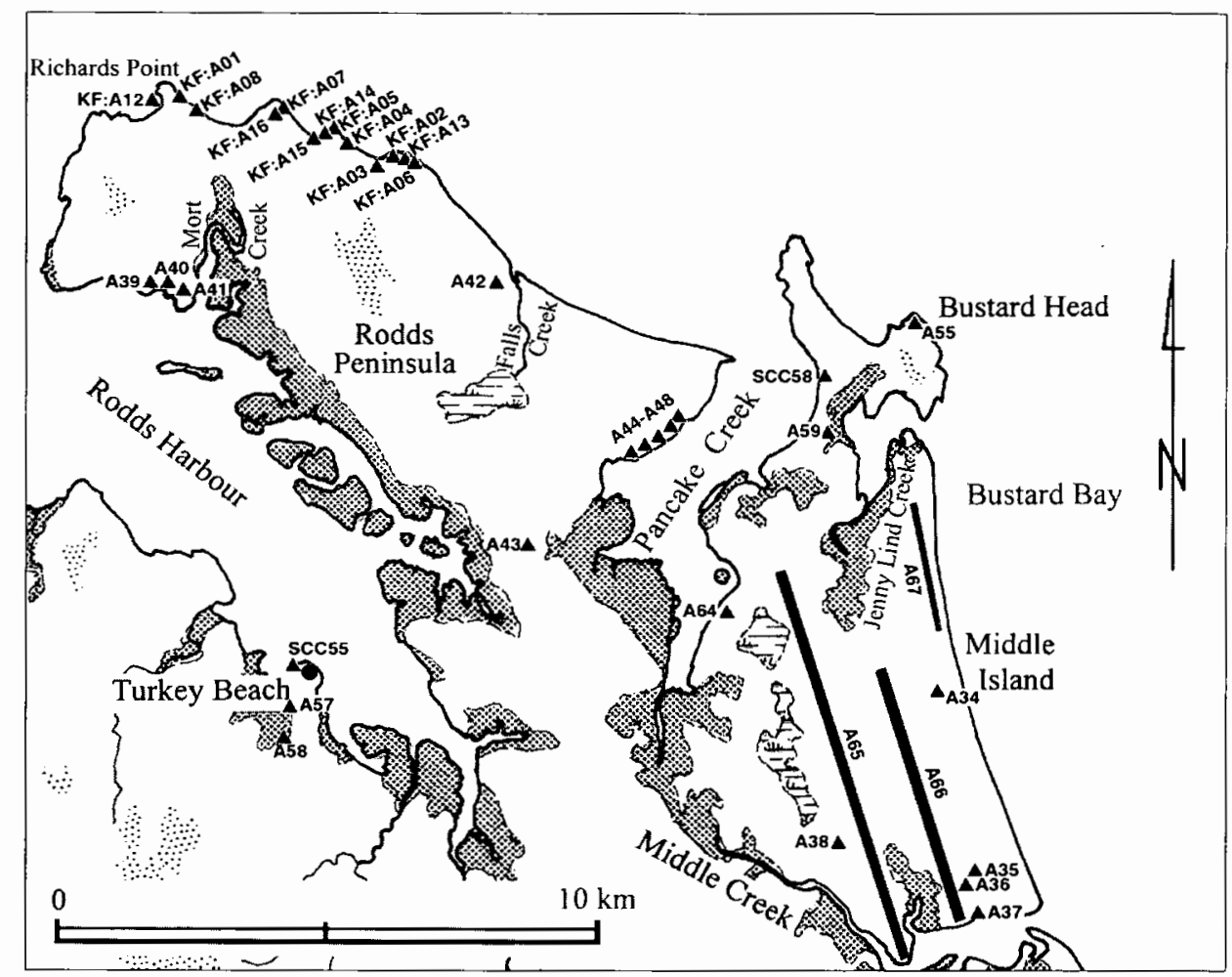

Figure 8. Northern segment of the study area showing recorded sites as triangles in the Middle Island, Rodds Peninsula and Turkey Beach areas (after Burke 1993; Lilley 1994; Lilley et al. 1997; Ulm 1999). Sites without a 'KF:' prefix are listed in Appendix A with the prefix 'KE:'. Sites listed with a 'SCC' prefix are currently unregistered sites.

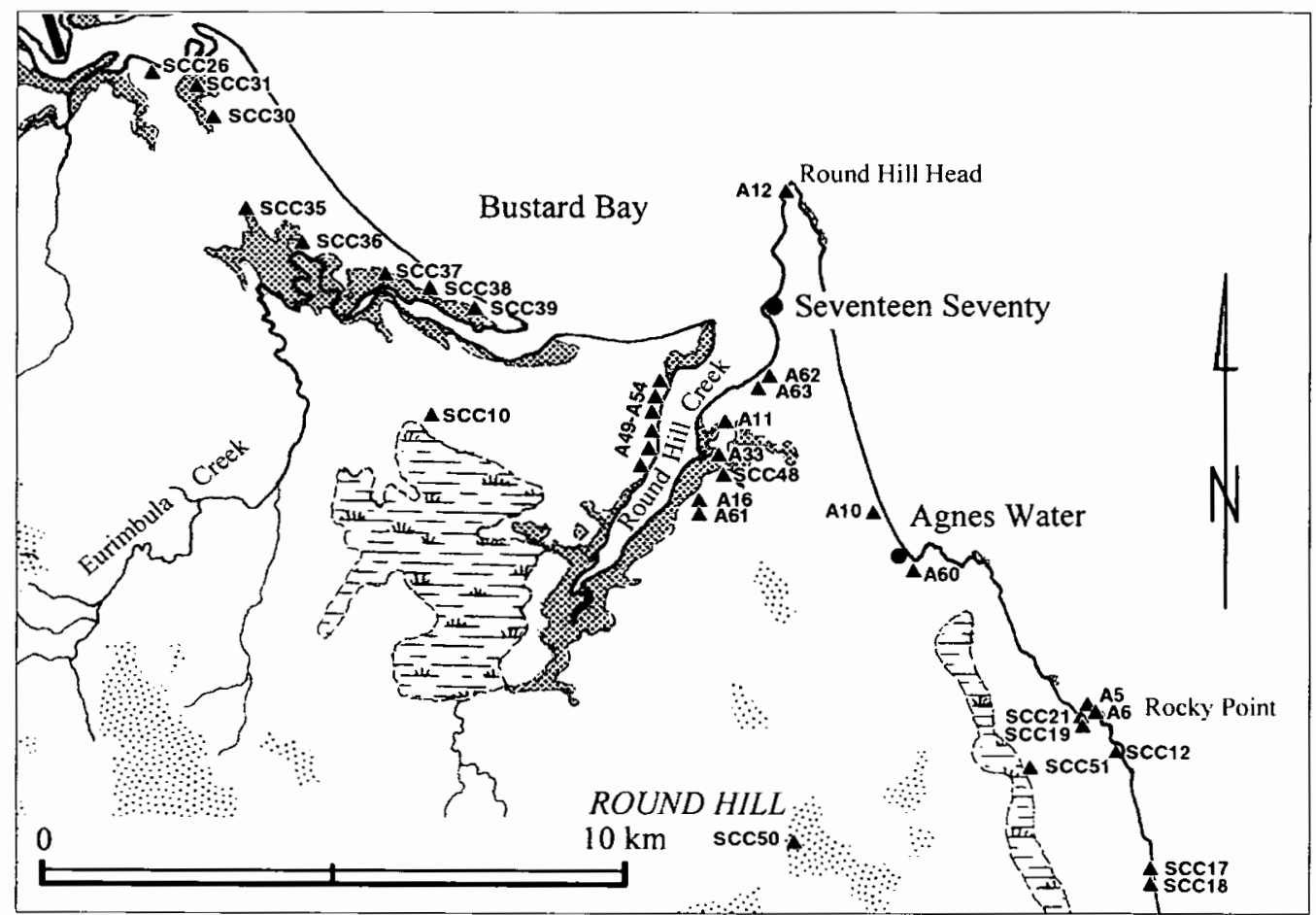

Figure 9. Southern segment of the study area showing recorded sites as triangles in the Agnes Water, Round Hill Creek and Eurimbula Creek areas (after Burke 1993; Lilley et al. 1997; Rowland 1987; Ulm 1999). Sites are listed in Appendix A with the prefix 'KE:'. Sites listed with a 'SCC' prefix are currently unregistered sites. 
Colonial impact, notably in the form of frontier violence and introduced diseases, precipitated the demographic collapse of local Aboriginal social groups and virtual abandonment of the near-coastal landscape by the late nineteenth-century. For the Tooloola of the Gladstone area to the immediate north, Curr (1887) estimated that by 1882 a preEuropean population of 700 had been reduced to 43 . During the 1850s, the Native Mounted Police were active in the region and several massacres are known to have occurred in the Miriam Vale area (Clarkson et al. in prep). In the main, by the late nineteenthcentury Aboriginal populations in the region coalesced into fringe camps at major European townships such as Miriam Vale in the west and Gladstone in the north (e.g. Roth 1898). Although Aboriginal people may have occasionally visited the area after the 1920s from local Aboriginal population centres such as Berajondo and Gladstone, the entire region was effectively depopulated by the removal of Aboriginal people to reserves and missions (particularly Barambah, Woorabinda and Bogimbah) under the provisions of the Aborigines Protection and Restriction of the Sale of Opium Act 1897 (Blake 1991; Evans 1991).

\section{Archaeological Surveys and Excavations Previous Research}

Prior to the 1990s, knowledge of the archaeological record of the study region was extremely limited. In fact, prior to 1993 only eight sites were recorded on the Queensland Environmental Protection Agency site index for the study area. In 1978, a quarry site and axe grinding grooves were recorded on the coast just south of Agnes Water and in 1986 two shell middens were recorded by Neal (1986) on the west bank of Seven Mile Creek as part of an environmental impact assessment. Also in 1986, Rowland (1987) conducted a "broad cursory investigation" of the study area as part of general surveys of the coast between Elliott Heads and Turkey Beach. Rowland (1987:17) noted that "substantial middens are rare", sites are located "either atop rocky headlands or in sheltered estuaries", and that "smaller scatters of shells are located along open beaches". He (1987:17) concluded that:

Whether this is a true reflection of Aboriginal settlement patterns in the area or an expression of geomorphological factors affecting preservation and visibility is a problem still to be resolved. Certainly the extent of erosion along the open coastal dune systems of the area would suggest that the loss of sites may be an important factor affecting the above pattern.

Godwin (1990) located an extensive midden on the west bank of Round Hill Creek during limited surveys of Eurimbula National Park (later registered as KE:A49-KE:A54). In 1993, Burke (1993) conducted selective systematic archaeological surveys in the region as part of a broad cultural heritage assessment between Agnes Water in the south and Raglan Creek in the north and up to $1 \mathrm{~km}$ inland from the mainland coast. In the southern Curtis Coast study area, Burke (1993) documented 93 sites, including shell middens $(n=77)$, stone artefact scatters $(n=12)$, quarries $(n=2)$, stone-walled fishtraps $(n=1)$ and scarred trees $(n=1)$. Overall, Burke (1993) found that sites were most commonly located on level or gently inclined sand dune surfaces in low-energy estuarine environments.

\section{Gooreng Gooreng Cultural Heritage Project}

Archaeological investigations conducted under the auspices of the Gooreng Gooreng Cultural Heritage Project commenced on the southern Curtis Coast in 1993, augmented by a number of cultural heritage impact studies undertaken by the authors (Lilley 1994, 1995). Together these investigations were designed to expand the results of earlier, more limited or project-specific surveys discussed above. Of particular interest were questions concerning the antiquity of human occupation in the coastal region and whether the concentration of sites in estuaries and near absence of material on ocean beaches noted by Rowland (1987) reflected past Aboriginal behaviour, recent geological processes or patterns of archaeological research. Up to the end of 1997, a total of 56 days of fieldwork (survey and excavation) had been undertaken on the southern Curtis Coast.

On the coast, systematic site surveys undertaken as transects were conducted in all major environmental zones including open beaches and rocky headlands, marine estuary systems, swamp and wetland margins, and the coastal ranges. To date, however, the majority of investigations have focused on near-coastal landscapes. The entire open coastline between Wreck Rock and Richards Point has been systematically surveyed as have the lower estuarine margins of Round Hill, Eurimbula, Middle, Jenny Lind, Pancake, Falls and Mort Creeks (Figure 1). Inland areas have proven more difficult to access owing to restricted access to freehold land, a lack of visibility and an absence of access tracks in many areas. The whole of Middle Island was intensively surveyed by Lilley (1994) using a grid of drilling-lines graded across the island for mineral sand exploration. Some small transects have also been undertaken on the northeast margin of a large swamp which dominates the western half of the Deepwater Section of Eurimbula National Park and parts of Round Hill National Park. Poor visibility away from coast and estuary margins is considered to be a major impediment to site detection (see also Burke 1993:23, 32-33). 


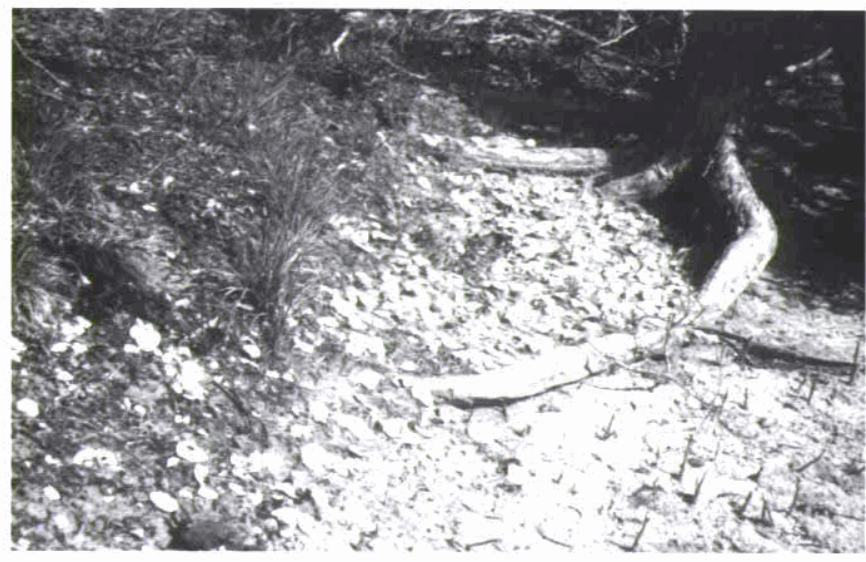

Figure 10. Mud ark (Anadara trapezia) scatter at the base of a low erosion bank, site KE:A33, facing south (Photograph: S. UIm).

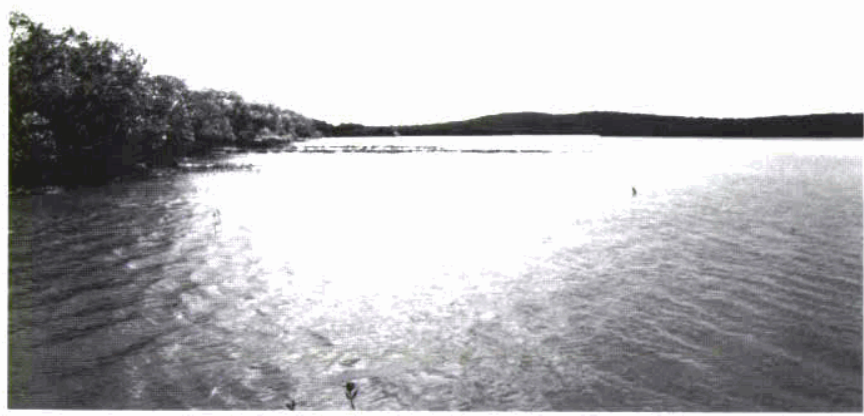

Figure 12. Stone-walled tidal fishtrap, Mort Creek, site KE:A41, facing north (Photograph: T. Eales).

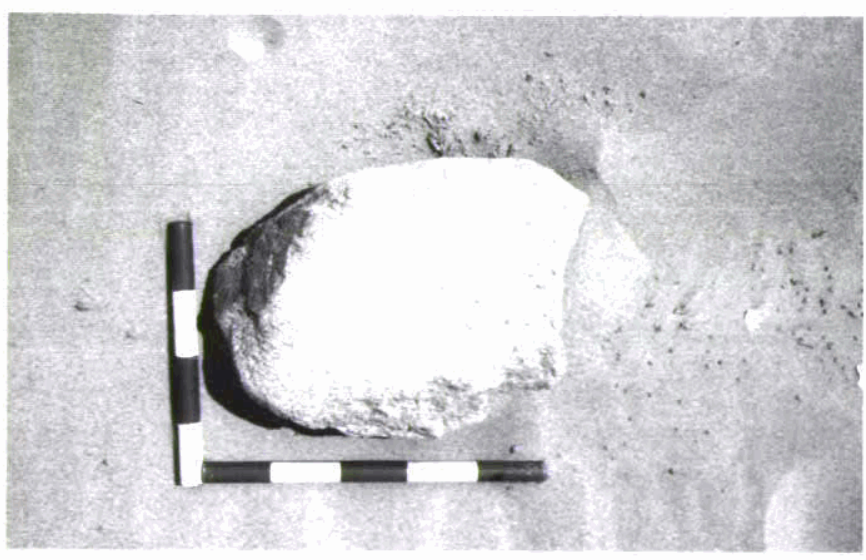

Figure 14. Microgranite grinding implement on an open sandmass, site KE:A67, facing south (Photograph: S. Ulm).

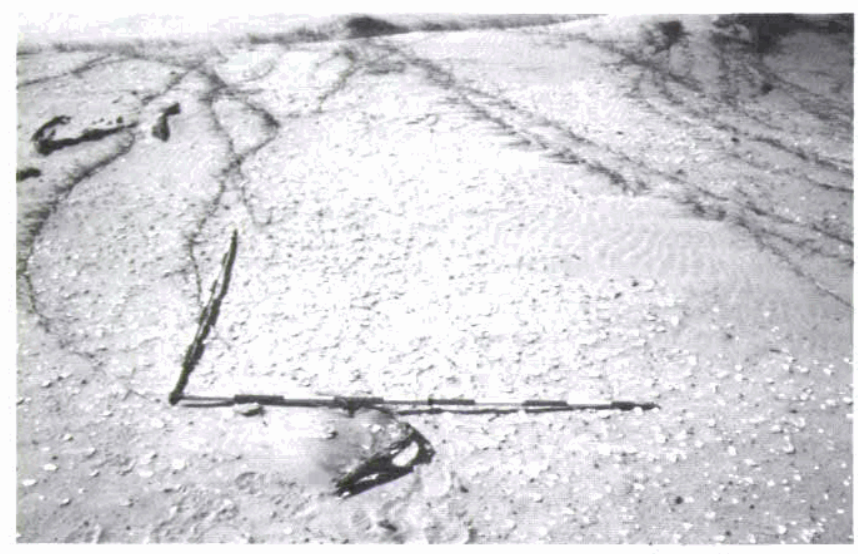

Figure 11. Pipi (Donax deltoides) scatter on an open sandmass, site KE:A67, facing north (Photograph: S. Ulm).

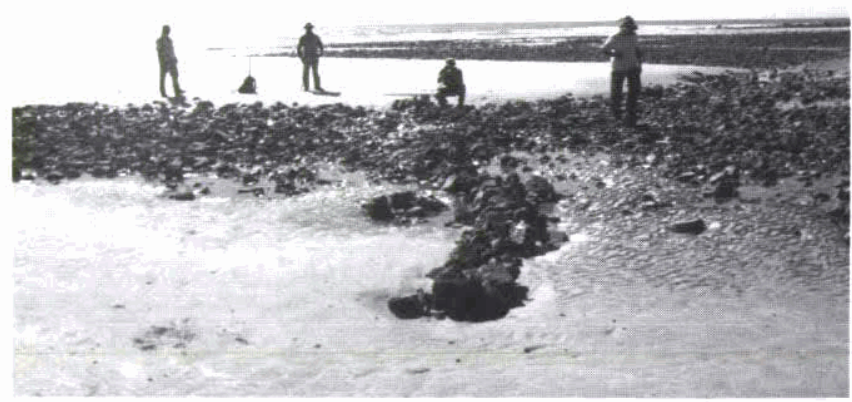

Figure 13. Stone-walled tidal fishtrap, Richards Point, site KF:A12, facing north (Photograph: I. Lilley).

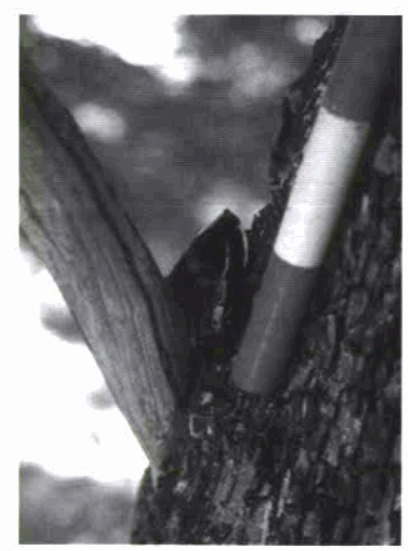

Figure 15. Retouched glass artefact in the fork of a quinine tree, site KE:A33, facing north (Photograph: S. Ulm). 
Survey crews were deployed so as to sample most effectively the different micro-environments that were encountered. The usual strategy involved walking through the subject area in line-abreast at one visual distance separation between walkers and up to $50 \mathrm{~m}$ in total width, focusing on areas of high groundsurface visibility. In some areas, the crew was split into two teams to examine different zones, such as foredunes and backdunes, simultaneously. While field crews took advantage of every opportunity to examine soil profiles in road cuttings, creek banks and the like, no excavation, augering or other subsurface testing was undertaken during the survey phase of the study (cf. Burke 1993:23-24). Site locations were established with the use of topographic maps, aerial photographs and Global Positioning System (GPS) readings.

\section{Survey Results}

A major complication in effectively conducting and evaluating archaeological survey data from the region was a lack of access to the earlier site recordings made by Burke (1993) held by the Queensland Environmental Protection Agency. Although abbreviated survey results are available in Burke's (1993) report, an absence of detailed site descriptions and inconsistencies in location data prevented accurate field identification of previously recorded sites. These details have recently been obtained under the provisions of the Freedom of Information Act 1992. As a result of these problems, some of the sites reported by Lilley et al. (1997:Table 2) had already been recorded by Burke (1993). Further confusion arose as some of the pre-allocated State site numbers assigned to Burke had already been allocated to other sites by the time they came to be registered (M. Carter, Queensland Environmental Protection Agency, pers. comm., 1999) and many of Burke's sites were subsequently conflated on the basis of proximity when entered onto the database (Burke's original 93 sites from this area were registered as only 51 sites). Additionally, Burke (1993:Appendix 5) assigned pre-allocated site numbers to more than one site on a number of occasions (KE:A37-KE:A40, KE:A44-KE:A46 in Appendix 5), which was not addressed during the registration process. It should be noted that most of the site numbers listed in QDEH (1994:Appendix XVI) were among Burke's (1993) pre-allocated site numbers, which were superceded when registered by the Queensland Environmental Protection Agency. To simplify the multiple site designations, Appendix B presents a key which links actually-registered sites to Burke's (1993) site field numbers and pre-allocated site designations, as well as those assigned by other researchers, including those employed by the Gooreng Gooreng Cultural
Heritage Project.

Appendix A is an attempt to synthesize the survey data for the area included in Rowland (1987), Burke (1993), Lilley et al. (1997) and the Queensland Environmental Protection Agency site database (obtained under the Freedom of Information Act, 1992). This task was complicated by variations in site definitions and recording strategies combined with problems in site provenience data related primarily to inadequate location data. For example, the site Lilley et al. (1997) and Ulm et al. (this volume) refer to as Eurimbula Site 1 (SCC43) is registered as six separate sites on the Queensland Environmental Protection Agency site database (KE:A49-KE:A54), which is a secondary conflation of Burke's (1993) original 20 separate sites.

Clearly, these variations would render as spurious any absolute quantitative comparisons between the sites presented in Appendix A. The general descriptions of the nature of observed archaeological materials, however, provide a basis for broadly characterizing the archaeological record of the study region.

A total of 79 Aboriginal cultural places is listed in Appendix A, including recording details, basic location data and a brief site description. In most cases this description includes all information available for the site. Figures 1 and 8-9 show site locations. Site types include stone quarries, axe grinding grooves, shell middens (Figures 10-11), stone-walled tidal fishtraps (Figures 12-13), stone artefact scatters, scarred trees and contact period sites. Low density shell middens are clearly the most common archaeological expression of Aboriginal behaviour in the area, dominated, without exception, by mud ark (Anadara trapezia) and/or commercial oyster (Saccostrea commercialis) (see also Burke 1993:40). Stone artefacts are commonly associated with larger shell middens (Figure 14) and rocky headlands. Lithic raw materials are dominated by locally available pyroclastic rhyolite and quartz with occasional non-local silcrete and banded chert artefacts. Flaked glass artefacts also occur on the surface of two large shell midden complexes (Figure 15). Several glass artefacts exhibit clear evidence of use in plant processing activities (Ulm et al. 1999).

Coupled with the results of previous studies, these extensive surveys have revealed a consistent pattern of site location. Extensive stratified shell midden deposits with evidence of multiple occupations and diverse activities are limited exclusively to tidal estuary margins in close proximity to their mouths. Such sites have been located on the northern and southern banks of Round Hill, Middle and Pancake Creeks. All are exposed in erosion faces extending over several kilometres. Relatively small, low density 
surface scatters of marine shell and stone artefacts made on local materials were noted on exposed headlands, while midden deposits on the open beaches themselves were generally very limited in extent and composition and often located in deflated contexts. Beach ridges and transgressive dunes located adjacent to the modern coastline contain abundant evidence for extensive but shallow site complexes (Lilley 1994; Lilley and Ulm 1995).

\section{Discussion of Survey Results}

At this stage it is unclear how processes of erosion and progradation on the exposed coast have affected the differential preservation and visibility of sites, as has been observed elsewhere (e.g. Bird 1992; Godfrey 1989; Head 1987; Rowland 1989). Intensive surveys of the open coastline suggest an almost complete absence of cultural material on the low frontal dunes bordering the open ocean beach and a preponderance of material on the lower margins of major estuaries. That this pattern is an accurate reflection of past Aboriginal behaviours rather than an artificial pattern created by differential preservation of cultural materials by erosion of the exposed coast is supported not only by the absence of material on current coasts, but also by the absence of cultural material on particular coastal landforms. Although scatters of midden shell and stone artefacts have been recorded on numerous headlands on the exposed coast, they are very sparse compared to the abundance of material on estuary margins suggesting a qualitative pattern of settlement preference in these areas. This pattern may in part reflect patterns of resource distribution with lower creek margin sites often situated adjacent to a range of potential resource zones. Significantly, despite the proximity of large midden deposits on the lower estuaries to open beach habitats (in some cases $<100 \mathrm{~m}$ ), only very occasional pipi (Donax deltoides) valves have been observed or recovered from excavated deposits. Only a single site in the region, the Middle Island Sandblow Site (KE:A67), exhibits significant quantities of this species. Donax deltoides is virtually the diagnostic signature of Aboriginal use of open coasts in southeast Queensland (e.g. Hall 1980; McNiven 1990, 1998). This pattern suggests that either this species was consumed and discarded at locations other than those identified, and which have been obscured or destroyed by erosional processes, or that the open coast was not a primary focus of resource extraction in this region.

McNiven $(1985,1989)$ identified a similar pattern at sites at the mouth of the Maroochy River and on the Inskip Point peninsula at Cooloola. He suggests that in southeast Queensland "major ocean beach shellfish (i.e. pipi) exploitation only occurred in contexts far removed from estuarine environments" (McNiven 1989:47), arguing that estuarine environments were preferentially exploited by people over the open beach owing to a greater productivity and diversity of resources in estuaries.

\section{Excavation Summary}

Two of the largest complexes of shell midden deposits in the area have been subject to limited test excavation (Figures 8 and 9): the Mort Creek Site Complex (KE:A41) on the west bank of Mort Creek at the northern end of Rodds Peninsula (Carter 1997; Carter et al. this volume; Lilley et al. 1996) and Eurimbula Site 1 (KE:A49-KE:A54) on the west bank of Round Hill Creek (Lilley et al. 1996; Ulm et al. this volume). Brief summaries of the excavations are presented below.

\section{Mort Creek Site Complex}

The Mort Creek Site Complex (KE:A41) is located on the west bank of Mort Creek on the west coast of Rodds Peninsula (Figure 8). The site consists of extensive areas of natural shell deposits (cheniers), cultural shell midden deposits and a stone-walled tidal fishtrap (Figures 3,12 ). Three $50 \mathrm{~cm} \times 50 \mathrm{~cm}$ test pits were excavated in different areas of the site in January 1995 in an attempt to distinguish areas of non-cultural deposit, such as cheniers, from shell middens. The excavation at 'White Patch' revealed a densely packed and highly fragmented shell deposit attributed to chenier development. It is characterized by a large range of species, including micro-molluscs. 'The Granites' excavation revealed cultural shell midden deposits, including stone artefacts and burnt fish bone, overlying a chenier deposit resting on microgranite bedrock. The excavation at 'A7' revealed more complex sediments, suggesting the interfingering of cultural and natural shell deposits.

Seven radiocarbon dates have been obtained for the site (Appendix C). The dates from the unequivocal cultural deposits at 'The Granites' suggest Aboriginal occupation before 2,300 cal BP (Wk-3941). Significantly, the radiocarbon dates from the chenier deposits suggest an overlap in the formation of natural and cultural shell deposits at the site. For further details see Carter et al. (this volume; also Carter 1997; Lilley et al. 1999; Lilley et al. 1996).

\section{Eurimbula Site 1}

Eurimbula Site 1 (KE:A49-KE:A54) is a large, stratified, midden complex intermittently exposed for some $2 \mathrm{~km}$ in a steep erosion face on the west bank of Round Hill Creek (Figure 9). Three $50 \mathrm{~cm} \times 50 \mathrm{~cm}$ test pits were excavated at $25 \mathrm{~m}$ intervals along each of three transects placed perpendicular to the erosion 
bank. Excavation yielded a cultural assemblage dominated by shellfish remains (mud ark and oyster), with small quantities of fish bone, charcoal and stone artefacts. Densities of cultural material were found to decrease markedly with distance from the creek.

Five radiocarbon dates are available for the site, revealing an occupational sequence spanning from c. 3,200 cal BP (Wk-3945) to the historical period (Appendix C). For further details see Ulm et al. (this volume; also Lilley et al. 1996; Reid 1997).

\section{Conclusion}

The overview presented in this paper is a baseline synthesis of known archaeological resources in the study area. This consolidation of data gathered by a variety of investigators will provide a starting point for field verification and further investigations.

These results confirm Aboriginal occupation of the coast in this region from at least 3,000 BP, and conforms with other dates obtained for the Queensland coast (Ulmet al. 1995; cf. Nicholson and Cane 1994). In particular, the dates are similar to the earliest dates obtained at the site of Booral in the Great Sandy Straits to the south (Bowen 1998; Frankland 1990) as well as those from the Keppel Islands just to the north (Rowland 1985, 1992).

The general structure of the archaeological record of the region is qualitatively similar to adjacent areas to the north (Burke 1993; Border 1994) and south (McNiven 1990, 1998) which have featured in discussions of late Holocene change in Aboriginal societies on the Queensland coast (e.g. McNiven 1999; Ulm and Hall 1996). The investigation of the archaeological resources of the southern Curtis Coast therefore has the potential to contribute to discussions of such wider issues.

\section{Acknowledgements}

The preliminary results discussed in this paper are based on fieldwork and analyses variously funded by the National Estate Grants Program of the Australian Heritage Commission, the Australian Institute of Aboriginal and Torres Strait Islander Studies (G97/6067 and G98/6113), the Australian Institute of Nuclear Sciences and Engineering (98/048) and the Aboriginal and Torres Strait Islander Studies Unit at the University of Queensland.

We thank the Gurang Land Council Aboriginal Corporation, the Central Queensland Native Title Claims Unit and the Queensland Environmental Protection Agency for continuing assistance and participation in the project. For their collaboration in fieldwork we are grateful to members of the Gooreng Gooreng Aboriginal community: Colin Johnson, Hilda Johnson, Mervyn Johnson, Michael Williams, Ron Johnson (Sr), Ron Johnson (Jr), Hilton (Charlie)
Johnson, Vicki Johnson, Connie Walker, George Walker, Cedric Williams, James Williams and Nathan Woolford.

Coastal surveys and excavations were conducted with the assistance of students including, Brit Asmussen, Greg Bowen, Deborah Brian, Melissa Carter, Chris Chicoteau, Chris Clarkson, Shane Coghill, Sebastian Crangle, Garrick Hitchcock, Lynette Hughes, Debbie Kilroy, Joe Kilroy, Vanessa Krueger, Sarah L'Estrange, Sean McBride, Carney Matheson, Catriona Murray, David Reid, Jill Reid, John Richter, Gail Robertson, Sarah Sheridan, Stephen Skelton, Linda Tebble, Sophie Thompson, Deb Vale and Catherine Westcott.

For help negotiating the Freedom of Information Act 1992, we are grateful to Catherine Westcott and Garrick Hitchcock of the Queensland Environmental Protection Agency. Thanks to John Richter for drafting the original Figures 1-3 and to Tony Eales for help in modifying them. Jill Reid (Aboriginal and Torres Strait Islander Studies Unit, University of Queensland) commented on several drafts.

\section{References Cited}

Beaglehole, J.C. (ed.) 1963 The Endeavour Journal of Joseph Banks 1768-1771. Sydney: Angus and Robertson.

Belperio, A.P. 1979 Negative evidence for a mid-Holocene high sea-level along the coastal plain of the Great Barrier Reef province. Marine Geology 32:M1-M9.

Bird, M.K. 1992 The impact of tropical cyclones on the archaeological record: An Australian example. Archaeology in Oceania 27(2):75-86.

Bladen, F.M. (ed.) 1892 Historical Records of New South Wales. Vol. 1. Sydney: Government Printer.

Blake, T.W. 1991 A Dumping Ground: Barambah Aboriginal Settlement 1900-40. Unpublished PhD thesis, Department of History, University of Queensland, Brisbane.

Border, A. 1994 Shoalwater Bay Military Training Area (SWBTA): A review of cultural heritage resources their significance and land use. In Commonwealth Commission of Inquiry Shoalwater Bay, Capricornia Coast, Queensland, Research Reports, pp.173-233. No. 5, Vol. A. Canberra: Australian Government Publishing Service.

Bowen, G. 1998 Towards a generic technique for dating stone fish traps and weirs. Australian Archaeology 47:39-43.

Brasch, S. 1975 Gureng Gureng, a Language of the Upper Burnett River, South-East Queensland. Unpublished B.A. (Hons) sub-thesis, Department of Linguistics, Australian National University, Canberra.

Buchanan, S. 1999 Lighthouse of Tragedy: The Story of Bustard Head Lighthouse, Queensland's First Coast Light. Samford: Coral Coast Publications. 
Burke, C. 1993 A Survey of Aboriginal Archaeological Sites on the Curtis Coast, Central Queensland. Unpublished report to the Queensland Department of Environment and Heritage, Rockhampton.

Carter, M. 1997 Chenier and Shell Midden: An Investigation of Cultural and Natural Shell Deposits at Rodds Peninsula, Central Queensland Coast. Unpublished B.A. (Hons) thesis, Department of Anthropology and Sociology, University of Queensland, Brisbane.

Carter, M., I. Lilley, S. Ulm and D. Brian this volume Mort Creek Site Complex, Curtis Coast: Site report. Queensland Archaeological Research 11.

Chappell, J. and J. Grindrod 1984 Chenier plain formation in northern Australia. In B. Thom (ed.), Coastal Geomorphology in Australia, pp.197-231. Sydney: Academic Press.

Clarkson, C., M. Williams, I. Lilley and S. Ulm in prep. Gooreng Gooreng Contemporary Social Landscapes. Aboriginal and Torres Strait Islander Studies Unit Research Report Series. Brisbane: Aboriginal and Torres Strait Islander Studies Unit, University of Queensland

Connah, T.H. 1961 Beach sand heavy mineral deposits of Queensland. Publications of the Geological Survey of Queensland 302. Brisbane: Queensland Department of Mines.

Curr, E.M. 1887 The Australian Race. Melbourne: Government Printer.

Davies, S. 1994 An Archaeological Assessment of the Proposed Rail Deviations on the Mainline Upgrade between Bundaberg and Gladstone, Queensland. UQASU Report 237. Brisbane: University of Queensland Archaeological Services Unit, Department of Anthropology and Sociology, University of Queensland.

Dowling, R.M. 1980 The mangrove vegetation. In H.F. Olsen, R.M. Dowling and D. Bateman 1980 Biological Resources Investigation (Estuarine Inventory), pp.4590. Queensland Fisheries Service Research Bulletin 2. Brisbane: Queensland Fisheries Service.

Ellis, P. and W. Whitaker 1976 Geology of the Bundaberg 1:250 000 Sheet Area. Geological Survey of Queensland Report 90. Brisbane: Queensland Department of Mines.

Endean, R., R. Kenny and W. Stephenson 1956 The ecology and distribution of intertidal organisms on the rocky shores of the Queensland mainland. Australian Journal of Marine and Freshwater Research 7(1):88146.

Evans, R. 1991 'A Permanent Precedent': Dispossession, Social Control and the Fraser Island Reserve and Mission, 1897-1904. Ngulaig 5. Brisbane: Aboriginal and Torres Strait Islander Studies Unit, University of Queensland.

Flinders, M. 1814 A Voyage to Terra Australis. 2 vols. London: G. and W. Nichol.
Frankland, K. 1990 Booral: A Preliminary Investigation of an Archaeological Site in the Great Sandy Region, Southeast Queensland. Unpublished B.A. (Hons) thesis, Department of Anthropology and Sociology, University of Queensland, Brisbane.

Godfrey, M.C.S. 1989 Shell midden chronology in southwestern Victoria: Reflections of change in prehistoric population and subsistence. Archaeology in Oceania 24(2):65-69.

Godwin, L. 1990 Cultural heritage. In J. McCosker, Eurimbula National Park Draft Management Plan. Unpublished report to the Queensland Department of Environment and Heritage, Rockhampton.

Grant, E. 1993 Grant's Guide to Fishes. $6^{\text {th }}$ ed. Scarborough: E.M. Grant Pty Ltd.

Growcott, V. and M. Taylor 1996 A Short History of Miriam Vale Shire: The Birthplace of Queensland: From the Journals of Arthur Jeffery. Miriam Vale: Miriam Vale Historical Society.

Hall, J. 1980 Minner Dint: A recent Aboriginal midden on Moreton Island, southeastern Queensland. In P.K. Lauer (ed.), Occasional Papers in Anthropology 10:94112. St Lucia: Anthropology Museum, University of Queensland.

Head, L. 1987 The Holocene prehistory of a coastal wetland system: Discovery Bay, southeastern Australia. Human Ecology 15(4):435-462.

Hopley, D. (ed.) 1983 Australian Sea-Levels in the Last 15000 Years: A Review. Occasional Papers 3. Townsville: Department of Geography, James Cook University of North Queensland.

Hopley, D. 1985 The Queensland coastline: Attributes and issues. In J.H. Holmes (ed.), Queensland: A Geographical Interpretation, pp.73-94. Brisbane: Booralong Publications.

Knox, G.A. 1963 The biogeography and intertidal ecology of the Australasian coasts. Oceanography and Marine Biology: An Annual Review 1:341-404.

Lambeck, K. and M. Nakada 1990 Late Pleistocene and Holocene sea-level change along the Australian coast. Palaeogeography, Palaeoclimatology, Palaecology 89:143-176.

Larcombe, P., R.M. Carter, J. Dye, M.K. Gagan and D.P. Johnson 1995 New evidence for episodic post-glacial sea-level rise, central Great Barrier Reef, Australia. Marine Geology 127:1-44.

Lilley, I. 1994 An Archaeological Assessment of Proposed Sand-Mining on Middle Island, Coastal Central Queensland. UQASU Report 244. Brisbane: University of Queensland Archaeological Services Unit, Department of Anthropology and Sociology, University of Queensland.

Lilley, I. 1995 An Archaeological Assessment of the Cultural Heritage Values of the Proposed Agnes Water Sewage Treatment Plant and Irrigation Area, Agnes Water, Coastal Central Queensland. Unpublished report to Kinhill Cameron McNamara Pty Ltd. 
Lilley, I., D. Brian and S. Ulm 1999 The use of foraminifera in the identification and analysis of marine shell middens: A view from Australia. In M-J. Mountain and D. Bowdery (eds), Taphonomy: The Analysis of Processes from Phytoliths to Megafauna, pp.9-16. Research Papers in Archaeology and Natural History 30. Canberra: Archaeology and Natural History Publications, Research School of Pacific and Asian Studies, Australian National University.

Lilley, I. and S. Ulm 1995 The Gooreng Gooreng Cultural Heritage Project: Some proposed directions and preliminary results of the archaeological program. Australian Archaeology 41:11-15.

Lilley, I., S. Ulm and D. Brian 1996 The Gooreng Gooreng Cultural Heritage Project: First radiocarbon determinations. Australian Archaeology 43:38-40.

Lilley, I., M. Williams and S. Ulm 1997 The Gooreng Gooreng Cultural Heritage Project: A Report on National Estate Grants Program Research, 1995-1996. 2 vols. Brisbane: Aboriginal and Torres Strait Islander Studies Unit, University of Queensland.

Lupton, C.J. and M.J. Heidenreich 1996 A Fisheries Resource Assessment of the Baffle Creek System in the Wide Bay-Burnett Region of Queensland. Department of Primary Industries Information Series QI96055(a). Brisbane: Department of Primary Industries.

MacGillivray, J. 1852 Narrative of the Voyage of H.M.S. Rattlesnake. London: T. and W. Boone.

McDonald, L. 1988 Gladstone: City that Waited. Brisbane: Boolarong Publications.

McNiven, I. 1985 An archaeological survey of the Cooloola Region, S.E. Queensland. Queensland Archaeological Research 2:4-37.

McNiven, I. 1989 Aboriginal shell middens at the mouth of the Maroochy River, southeast Queensland. Queensland Archaeological Research 6:28-52.

McNiven, I. 1990 Prehistoric Aboriginal Settlement and Subsistence in the Cooloola Region, Coastal Southeast Queensland. Unpublished PhD thesis, Department of Anthropology and Sociology, University of Queensland, Brisbane.

McNiven, I. 1998 Aboriginal archaeology of the Corroboree Beach dune field, Fraser Island: Re-survey and re-assessment. Memoirs of the Queensland Museum, Cultural Heritage Series 1(1):1-22.

McNiven, I. 1999 Fissioning and regionalisation: The social dimensions of changes in Aboriginal use of the Great Sandy Region, southeast Queensland. In J. Hall and I. McNiven (eds), Australian Coastal Archaeology, pp.157-168. Research Papers in Archaeology and Natural History 31. Canberra: Archaeology and Natural History Publications, Research School of Pacific and Asian Studies, Australian National University.

Mathew, J.H. 1914 Note on the Gurang Gurang tribe of Queensland, with vocabulary. Proceedings of the Australian Association for the Advancement of Science 14:433-443.
Neal, R.A. 1986 Results of the Archaeological Inspection of Proposed Telecom DRCS and Broadband Locations for December 1986. Unpublished report to Telecom Australia.

Nicholson, A. and S. Cane 1994 Pre-European coastal settlement and use of the sea. Australian Archaeology 39:108-117.

Olsen, H.F. 1980a Estuarine resource inventory and evaluation for the coastal strip between Round Hill Head and Tannum Sands, Queensland. In H.F. Olsen, R.M. Dowling and D. Bateman 1980 Biological Resources Investigation (Estuarine Inventory), pp.1-44. Queensland Fisheries Service Research Bulletin 2. Brisbane: Queensland Fisheries Service.

Olsen, H.F. 1980b Sea-grasses (Occurrence and Distribution). In H.F. Olsen, R.M. Dowling and D. Bateman 1980 Biological Resources Investigation (Estuarine Inventory), pp.91-94. Queensland Fisheries Service Research Bulletin 2. Brisbane: Queensland Fisheries Service.

Oxley, J. 1825 Report of an expedition to survey Port Curtis, Moreton Bay and Port Bowen. In B. Field (ed.), Geographical Memoirs of New South Wales, pp.1-26. London: John Murray.

Pearson, G.W. and M. Stuiver 1993 High-precision bidecadal calibration of the radiocarbon time scale, 500-2500 BC. Radiocarbon 35(1):25-33.

QDEH 1994 Curtis Coast Study: Resource Report. Rockhampton: Department of Environment and Heritage.

QDOT 1998 The Official Tide Tables and Boating Safety Guide 1998. Brisbane: Queensland Department of Transport.

Reid, J. 1997 Results and Analysis of E1: An Investigation of the Archaeological Record of the Eurimbula Shell Midden Complex, Central Queensland Coast. Unpublished report submitted for ID232: Independent Project in Aboriginal and Torres Strait Islander Studies I, Aboriginal and Torres Strait Islander Studies Unit, University of Queensland.

Reid, J. 1998 An Archaeological Approach to Quarry Studies: A Technological Investigation of the Ironbark Site Complex, Southern Curtis Coast, Australia. Unpublished B.A. (Hons) thesis, Department of Anthropology and Sociology, University of Queensland, Brisbane.

Roth, W.E. 1898 The Aborigines of the Rockhampton and Surrounding Districts, A Report to the Commissioner of Police. Unpublished manuscript, Mitchell Library, Sydney.

Roughley, T.C. 1928 The Oyster Resources of Queensland. Unpublished report to the Queensland Department of Harbours and Marine, Brisbane.

Rowland, M.J. 1985 Further radiocarbon dates from Mazie Bay, North Keppel Island. Australian Archaeology 21:113-118.

Rowland, M.J. 1987 Preliminary Archaeological Survey of 
Coastal Areas of the Bundaberg 1:250,000 Sheet (KE). Unpublished report to the Queensland Department of Environment and Heritage, Brisbane.

Rowland, M.J. 1989 Population increase, intensification or a result of preservation?: Explaining site distribution patterns on the coast of Queensland. Australian Aboriginal Studies 2:32-41.

Rowland, M.J. 1992 Conservation Plan for Cultural Heritage Sites on the Keppel Island Group, Central Queensland. Unpublished report to the Livingstone Shire Council and National Parks and Wildlife Branch, Division of Conservation, Department of Environment and Heritage, Brisbane.

Shanco, P. and R. Timmins 1975 Reconnaissance of southern Bustard Bay tidal wetlands. Operculum October: 149-154.

Stevens, N. 1968 Triassic Volcanic Rocks of Agnes Water, Queensland. University of Queensland Papers, Department of Geology 6(6):147-155.

Stuiver, M. and T.F. Braziunas 1993 Modeling atmospheric ${ }^{14} \mathrm{C}$ influences and ${ }^{14} \mathrm{C}$ ages of marine samples to 10,000 BC. Radiocarbon 35(1):137-189.

Stuiver, M. and G.W. Pearson 1993 High-precision bidecadal calibration of the radiocarbon time scale, $\mathrm{AD}$ 1950-500 BC and 2500-6000 BC. Radiocarbon 35(1):1-23.

Stuiver, M. and P.J. Reimer 1993 Extended ${ }^{14} \mathrm{C}$ data base and revised CALIB $3.0{ }^{14} \mathrm{C}$ age calibration program. Radiocarbon 35(1):215-230.

Thom, B.G. and P.S. Roy 1983 Sea-level change in New South Wales over the past 15,000 years. In D. Hopley (ed.), Australian Sea-Levels in the Last 15000 Years: A
Review, pp.64-84. Occasional Papers 3. Townsville: Department of Geography, James Cook University of North Queensland.

Tindale, N.N. 1974 Aboriginal Tribes of Australia. Berkeley: University of California Press.

Ulm, S. 1999 The Archaeology of the Curtis Coast Region Stage II: Final Report Statement to the Australian Institute of Aboriginal and Torres Strait Islander Studies. Unpublished report to the Australian Institute of Aboriginal and Torres Strait Islander Studies, Canberra.

Ulm, S., B. Barker, A. Border, J. Hall, I. Lilley, I. McNiven, R. Neal and M. Rowland 1995 Pre-European coastal settlement and use of the sea: A view from Queensland. Australian Archaeology 41:24-26.

Ulm, S., M. Carter, J. Reid and I. Lilley this volume Eurimbula Site 1, Curtis Coast: Site report. Queensland Archaeological Research 11.

Ulm, S., T. Eales and S. L'Estrange 1999 Post-European Aboriginal occupation of the southern Curtis Coast, Central Queensland. Australian Archaeology 48:42-43.

Ulm, S. and J. Hall 1996 Radiocarbon and cultural chronologies in southeast Queensland prehistory. In S. Ulm, I. Lilley and A. Ross (eds), Australian Archaeology '95: Proceedings of the 1995 Australian Archaeological Association Annual Conference, pp.4562. Tempus 6. St Lucia: Anthropology Museum, Department of Anthropology and Sociology, University of Queensland.

Williams, M. 1981 Traditionally, My Country and its People. Unpublished MPhil (Qual.) thesis, Griffith University, Brisbane. 
Appendix A. List of Recorded Archaeological Sites on the Southern Curtis Coast.

\begin{tabular}{|c|c|c|c|c|}
\hline Site ID & Site Type & Recorder & Location & Description \\
\hline KE:A05 & $\begin{array}{l}\text { Stone } \\
\text { Quarry }\end{array}$ & $\begin{array}{l}\text { P. Smith } \\
1.11 .1980 \\
\text { C. Burke } \\
26.3 .93\end{array}$ & $\begin{array}{l}24^{\circ} 14^{\prime} 09^{\prime \prime} \\
151^{\circ} 56^{\prime} 10^{\prime \prime}\end{array}$ & $\begin{array}{l}\text { Stone quarry on a quartzite outcrop }\left(c .400 \mathrm{~m}^{2}\right) \text { within a sandstone headland, } \\
\text { adjacent to the coastline at Rocky Point. High density artefact exposure, } \\
\text { including a backed blade, scraper, two hammerstones and many small flakes. } \\
\text { Burke observed large numbers of artefacts during a } 1993 \text { visit, although Reid } \\
\text { failed to identify any unambiguous artefacts during a } 1998 \text { visit and called } \\
\text { into question the cultural status of the stone exposure. References: Burke } \\
\text { (1993); Lilley et al. (1997); Reid (1998). }\end{array}$ \\
\hline KE:A06 & $\begin{array}{l}\text { Axe } \\
\text { Grinding } \\
\text { Locality }\end{array}$ & $\begin{array}{l}\text { P. Smith } \\
1.11 .1980\end{array}$ & $\begin{array}{l}24^{\circ} 14^{\prime} 09^{\prime \prime} \\
151^{\circ} 56^{\prime} 10^{\prime \prime}\end{array}$ & $\begin{array}{l}\text { Grinding grooves in sandstone, on a headland adjacent to the coastline at } \\
\text { Agnes Water, c.35m from KE:A05. This site could not be relocated during } \\
\text { a field inspection in 1998. References: Reid (1998). }\end{array}$ \\
\hline $\mathrm{KE}: \mathrm{A} 08$ & $\begin{array}{l}\text { Shell } \\
\text { Midden/ } \\
\text { Artefact } \\
\text { Scatter }\end{array}$ & $\begin{array}{l}\text { R. Neal } \\
25.6 .86\end{array}$ & $\begin{array}{l}24^{\circ} 04^{\prime} 00^{\prime \prime} \\
151^{\circ} 30^{\prime} 00^{\prime \prime}\end{array}$ & $\begin{array}{l}\text { Sparse shell and stone artefact scatter exposed in sand vehicle tracks on a } \\
\text { sloping dune adjacent to a rocky foreshore and mangrove swamp near Seven } \\
\text { Mile Creek. Comprises mud ark (60\%), club shell (20\%) and oyster }(20 \%) \\
\text { and artefacts manufactured on quartz }(50 \%) \text {, black volcanic }(10 \%) \text { and } \\
\text { rhyolite }(40 \%) \text {. References: Neal (1986). }\end{array}$ \\
\hline KE:A09 & $\begin{array}{l}\text { Shell } \\
\text { Midden }\end{array}$ & $\begin{array}{l}\text { R. Neal } \\
25.6 .86\end{array}$ & $\begin{array}{l}24^{\circ} 04^{\prime} 00^{\prime \prime} \\
151^{\circ} 31^{\prime} 00^{\prime \prime}\end{array}$ & $\begin{array}{l}\text { Shell midden spotted from the air on a beach ridge adjacent to Seven Mile } \\
\text { Creek bordered by a freshwater swamp. Rowland could not locate this site } \\
\text { during a field inspection in } 1986 \text { and local informants suggested that it was } \\
\text { quartz tailings from quarrying activities rather than a midden deposit. } \\
\text { References: Neal (1986); Rowland (1987). }\end{array}$ \\
\hline KE:A10 & $\begin{array}{l}\text { Shell } \\
\text { Midden/ } \\
\text { Artefact } \\
\text { Scatter }\end{array}$ & $\begin{array}{l}\text { M. Rowland } \\
30.10 .86\end{array}$ & $\begin{array}{l}24^{\circ} 11^{\prime} 00^{\prime \prime} \\
151^{\circ} 52^{\prime} 00^{\prime \prime}\end{array}$ & $\begin{array}{l}\text { Five small low density surface shell scatters in eroding foredunes and } \\
\text { deflated dunes on the ocean beach just north of Agnes Water. Includes pipi, } \\
\text { oyster, nerite and occasional stone artefacts. References: Lilley et al. (1997); } \\
\text { Rowland (1987). }\end{array}$ \\
\hline $\mathrm{KE}: \mathrm{A} 11$ & $\begin{array}{l}\text { Shell } \\
\text { Midden }\end{array}$ & $\begin{array}{l}\text { M. Rowland } \\
30.10 .86 \\
\text { C. Burke } \\
22.4 .93\end{array}$ & $\begin{array}{l}24^{\circ} 10^{\prime} 58^{\prime \prime} \\
151^{\circ} 52^{\prime} 47^{\prime \prime}\end{array}$ & $\begin{array}{l}\text { Extensive shell midden complex bordering Round Hill Creek and bounded } \\
\text { in the south by Tom's Creek, an eastern tributary of Round Hill Creek. Size } \\
\text { not accurately determined owing to heavy vegetation. Material scattered on } \\
\text { all } 4 \text { WD tracks examined in the area. Maximum depth in all these locations } \\
\text { is } 10-20 \mathrm{~cm} \text {. Predominantly mud ark and oyster, with some stone artefacts. } \\
\text { Site complex covers a large area and probably subsumes the sites registered } \\
\text { separately as KE:A33, KE:A62 and KE:A63. References: Burke (1993); } \\
\text { Rowland (1987). }\end{array}$ \\
\hline KE:A12 & $\begin{array}{l}\text { Stone } \\
\text { Quarry/ } \\
\text { Shell } \\
\text { Midden/ } \\
\text { Artefact } \\
\text { Scatter }\end{array}$ & $\begin{array}{l}\text { M. Rowland } \\
1.11 .86 \\
\text { C. Burke } \\
29.4 .93\end{array}$ & $\begin{array}{l}24^{\circ} 09^{\prime} 00^{\prime \prime} \\
151^{\circ} 53^{\prime} 04^{\prime \prime}\end{array}$ & $\begin{array}{l}\text { Site consists of the entire Round Hill Head headland. Isolated stone artefacts } \\
\text { and artefact scatters located along exposed walking tracks and ridges. Two } \\
\text { large pyroclastic rhyolite boulders near the navigation beacon at the tip of } \\
\text { the headland exhibit a number of negative flake scars. Some oyster shell and } \\
\text { flaking debris is scattered in surrounding crevices. Elsewhere, scattered shell } \\
\text { fragments and stone artefacts occur, including cobble cores. References: } \\
\text { Burke (1993); Lilley et al. (1997); Rowland (1987). }\end{array}$ \\
\hline KE:A16 & $\begin{array}{l}\text { Shell } \\
\text { Midden }\end{array}$ & $\begin{array}{l}\text { M. Rowland } \\
24.7 .90 \\
\text { L. Godwin } \\
4.10 .90 \\
\text { C. Burke } \\
30.4 .93\end{array}$ & $\begin{array}{l}24^{\circ} 12^{\prime} 10^{\prime \prime} \\
151^{\circ} 51^{\prime} 56^{\prime \prime}\end{array}$ & $\begin{array}{l}\text { Multi-component stratified shell mound (at least } 16 \mathrm{~m} \times 10 \mathrm{~m})\left(\mathrm{c} .160 \mathrm{~m}^{2}\right) \text { with } \\
\text { a depth of more than } 50 \mathrm{~cm} \text {, located in open woodland on a low rock terrace } \\
\text { c. } 25 \mathrm{~m} \text { from Round Hill Creek. Extremely high density and spatially discrete } \\
\text { shell deposit, dominated by mud ark, but also some oyster, stone artefacts, } \\
\text { bone and charcoal. References: Burke (1993); Rowland (1987). }\end{array}$ \\
\hline KE:A32 & $\begin{array}{l}\text { Contact } \\
\text { Site }\end{array}$ & $\begin{array}{l}\text { S. Davies } \\
2.2 .94\end{array}$ & $\begin{array}{l}24^{\circ} 20^{\prime} 20^{\prime \prime} \\
151^{\circ} 34^{\prime} 00^{\prime \prime}\end{array}$ & $\begin{array}{l}\text { Miriam Vale Homestead and Cattle Station built c. } 1856 \text {. Historic and } \\
\text { contact site, located just southeast of the modern town of Miriam Vale. The } \\
\text { Station is the centre of religious and social affiliation to country for many } \\
\text { Aboriginal families whose association to the Miriam Vale area spanned the } \\
\text { pastoral occupation and into the distant past. This area was the location of } \\
\text { several massacres and conflicts between white pastoralists, Native Mounted } \\
\text { Police and Aborigines, including a major Aboriginal attack on } 12 \text { February } \\
1857 \text {. After the establishment of the Homestead and until the time of the } \\
\text { attacks, local Aborigines had been employed on the station. An Aboriginal } \\
\text { camp was situated on the south bank of House Creek adjacent to the } \\
\text { Homestead. References: Clarkson et al. (in prep.); Davies (1994). }\end{array}$ \\
\hline
\end{tabular}




\begin{tabular}{|c|c|c|c|c|}
\hline Site ID & Site Type & Recorder & Location & Description \\
\hline KE:A33 & $\begin{array}{l}\text { Shell } \\
\text { Midden }\end{array}$ & $\begin{array}{l}\text { C. Burke } \\
22.4 .93\end{array}$ & $\begin{array}{l}24^{\circ} 11^{\prime} 40^{\prime \prime} \\
151^{\circ} 52^{\prime} 30^{\prime \prime}\end{array}$ & 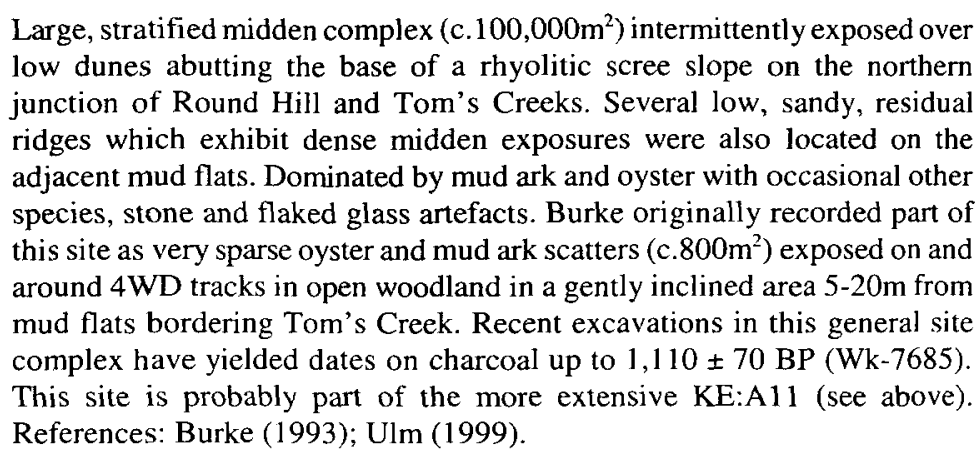 \\
\hline $\mathrm{KE}: \mathrm{A} 34$ & $\begin{array}{l}\text { Shell } \\
\text { Midden/ } \\
\text { Artefact } \\
\text { Scatter }\end{array}$ & $\begin{array}{l}\text { C. Burke } \\
27.1 .93\end{array}$ & $\begin{array}{l}24^{\circ} 04^{\prime} 25^{\prime \prime} \\
151^{\circ} 45^{\prime} 36^{\prime \prime}\end{array}$ & $\begin{array}{l}\text { Very sparse, surface scatter of shell and stone artefacts }\left(c .2,500 \mathrm{~m}^{2}\right) \text { located } \\
\text { on a graded survey line on a sand ridge c. } 1 \mathrm{~km} \text { inland from the central east } \\
\text { coast of Middle Island. Oyster }(\mathrm{n}=20) \text {, mud ark }(\mathrm{n}=10) \text { and stone artefacts } \\
(\mathrm{n}=3) \text {. References: Burke }(1993) \text {. }\end{array}$ \\
\hline KE:A35 & $\begin{array}{l}\text { Shell } \\
\text { Midden }\end{array}$ & $\begin{array}{l}\text { C. Burke } \\
27.1 .93\end{array}$ & $\begin{array}{l}24^{\circ} 06^{\prime} 49^{\prime \prime} \\
151^{\circ} 46^{\prime} 19^{\prime \prime}\end{array}$ & $\begin{array}{l}\text { Very sparse, surface shell scatter }\left(\mathrm{c} .20 \mathrm{~m}^{2}\right) \text { on top of a ridge on the southeast } \\
\text { of Middle Island. Contains only } 5 \text { oyster fragments, no artefacts. This site is } \\
\text { probably part of the larger site complex recorded by Lilley, registered as } \\
\text { KE:A66. References: Burke (1993); Lilley (1994). }\end{array}$ \\
\hline KE:A36 & $\begin{array}{l}\text { Shell } \\
\text { Midden }\end{array}$ & $\begin{array}{l}\text { C. Burke } \\
27.1 .93\end{array}$ & $\begin{array}{l}24^{\circ} 06^{\prime} 47^{\prime \prime} \\
151^{\circ} 46^{\prime} 19^{\prime \prime}\end{array}$ & $\begin{array}{l}\text { Very sparse, surface shell scatter }\left(\mathrm{c} .1 \mathrm{~m}^{2}\right) \text { consisting of only three oyster } \\
\text { shells on the southeast of Middle Island. This site is probably part of the } \\
\text { larger site complex recorded by Lilley, registered as KE:A66. References: } \\
\text { Burke (1993); Lilley (1994). }\end{array}$ \\
\hline KE:A37 & $\begin{array}{l}\text { Shell } \\
\text { Midden }\end{array}$ & $\begin{array}{l}\text { C. Burke } \\
30.1 .93\end{array}$ & $\begin{array}{l}24^{\circ} 07^{\prime} 16^{\prime \prime} \\
151^{\circ} 46^{\prime} 41^{\prime \prime}\end{array}$ & $\begin{array}{l}\text { A sparse, surface shell scatter }\left(c .1,500 \mathrm{~m}^{2}\right) \text { disturbed by construction } \\
\text { activities, located on a dune ridge on the southeast end of Middle Island. } \\
\text { Dominated by oyster, but includes mud ark and mussel. This site is probably } \\
\text { part of the larger site complex recorded by Lilley, registered as KE:A66 and } \\
\text { also exposed in the north erosion bank of Middle Creek. References: Burke } \\
\text { (1993); Lilley (1994); Lilley et al. (1997). }\end{array}$ \\
\hline $\mathrm{KE}: \mathrm{A} 38$ & $\begin{array}{l}\text { Shell } \\
\text { Midden }\end{array}$ & $\begin{array}{l}\text { C. Burke } \\
30.1 .93\end{array}$ & $\begin{array}{l}24^{\circ} 06^{\prime} 08^{\prime \prime} \\
151^{\circ} 45^{\prime} 04^{\prime \prime}\end{array}$ & $\begin{array}{l}\text { Sparse, surface shell scatter }\left(\mathrm{c} .2,000 \mathrm{~m}^{2}\right) \text { containing one stone artefact on a } \\
\text { ridge on the southwest of Middle Island. This site is probably part of the } \\
\text { larger site complex recorded by Lilley, registered as KE:A65. References: } \\
\text { Burke (1993); Lilley (1994). }\end{array}$ \\
\hline KE:A39 & $\begin{array}{l}\text { Shell } \\
\text { Midden }\end{array}$ & $\begin{array}{l}\text { C. Burke } \\
6.3 .93\end{array}$ & $\begin{array}{l}24^{\circ} 00^{\prime} 38^{\prime \prime} \\
151^{\circ} 37^{\prime} 26^{\prime \prime}\end{array}$ & $\begin{array}{l}\text { Sparse, surface shell scatter }\left(\mathrm{c} .50 \mathrm{~m}^{2}\right) \text { in an open area on a bank above the } \\
\text { beach fronting Rodds Harbour on the northwest end of Rodds Peninsula. } \\
\text { Dominated by mud ark with some oyster and mussel. References: Burke } \\
\text { (1993). }\end{array}$ \\
\hline KE:A40 & $\begin{array}{l}\text { Shell } \\
\text { Midden }\end{array}$ & $\begin{array}{l}\text { C. Burke } \\
6.3 .93\end{array}$ & $\begin{array}{l}24^{\circ} 00^{\prime} 47^{\prime \prime} \\
151^{\circ} 37^{\prime} 37^{\prime \prime}\end{array}$ & $\begin{array}{l}\text { Very sparse, surface shell scatter }\left(\mathrm{c} .50 \mathrm{~m}^{2}\right) 10 \mathrm{~m} \text { from beach fronting Rodds } \\
\text { Harbour and } 100 \mathrm{~m} \text { from the sea at low tide c.5masl on the northwest end of } \\
\text { Rodds Peninsula. Dominated by oyster with some mud ark. References: } \\
\text { Burke (1993). }\end{array}$ \\
\hline KE:A41 & $\begin{array}{l}\text { Shell } \\
\text { Midden/ } \\
\text { Artefact } \\
\text { Scatter }\end{array}$ & $\begin{array}{l}\text { C. Burke } \\
6.3 .93\end{array}$ & $\begin{array}{l}24^{\circ} 00^{\prime} 51^{\prime \prime} \\
151^{\circ} 37^{\prime} 43^{\prime \prime}\end{array}$ & $\begin{array}{l}\text { Extensive areas of natural shell deposits (cheniers), cultural shell midden } \\
\text { deposits and a stone-walled tidal fishtrap located on the west bank of Mort } \\
\text { Creek on the west coast of Rodds Peninsula. Shell exposures cover an area } \\
\text { in excess of c. } 6,000 \mathrm{~m}^{2} \text {. Species include mud ark, oyster and club shell. Stone } \\
\text { artefacts and fish bone noted in some excavations. Recent excavations } \\
\text { returned a date on shell of } 3,430 \pm 140 \mathrm{BP} \text { (Wk-6986). References: Burke } \\
\text { (1993); Carter (1997); Carter et al. (this volume); Lilley et al. (1996); Lilley } \\
\text { et al. (1997). }\end{array}$ \\
\hline KE:A42 & $\begin{array}{l}\text { Shell } \\
\text { Midden }\end{array}$ & $\begin{array}{l}\text { C. Burke } \\
7.3 .93\end{array}$ & $\begin{array}{l}24^{\circ} 00^{\prime} 38^{\prime \prime} \\
151^{\circ} 41^{\prime} 18^{\prime \prime}\end{array}$ & $\begin{array}{l}\text { Sparse, stratified shell scatter }\left(\mathrm{c} .100 \mathrm{~m}^{2}\right) \text { on a ridge near Falls Creek on the } \\
\text { central east coast of Rodds Peninsula. Includes oyster and turbo. Site located } \\
500 \mathrm{~m} \text { from sea and rocks. References: Burke (1993). }\end{array}$ \\
\hline $\mathrm{KE}: \mathrm{A} 43$ & $\begin{array}{l}\text { Shell } \\
\text { Midden }\end{array}$ & $\begin{array}{l}\text { C. Burke } \\
7.3 .93\end{array}$ & $\begin{array}{l}24^{\circ} 03^{\prime} 24^{\prime \prime} \\
151^{\circ} 41^{\prime} 48^{\prime \prime}\end{array}$ & $\begin{array}{l}\text { Group of midden exposures }\left(\mathrm{c} .900 \mathrm{~m}^{2}\right) \text { located on low residual beach ridges } \\
\text { stranded on mud flats at the western extremities of Pancake Creek consisting } \\
\text { of a shallow, linear midden exposed in a low erosion bank and three sparse } \\
\text { shell scatters. Includes oyster, mud ark, thaid, club shell and mussel. } \\
\text { References: Burke (1993). }\end{array}$ \\
\hline
\end{tabular}




\begin{tabular}{|c|c|c|c|c|}
\hline Site ID & Site Type & Recorder & Location & Description \\
\hline KE:A44 & $\begin{array}{l}\text { Shell } \\
\text { Midden }\end{array}$ & $\begin{array}{l}\text { C. Burke } \\
9.3 .93\end{array}$ & $\begin{array}{l}24^{\circ} 02^{\prime} 22^{\prime \prime} \\
151^{\circ} 42^{\prime} 49^{\prime \prime}\end{array}$ & $\begin{array}{l}\text { Large stratified shell midden }\left(\mathrm{c} .8,320 \mathrm{~m}^{2}\right) \text { on top of a ridge above the beach } \\
\text { and mud flats on the north bank of Pancake Creek, } 100 \mathrm{~m} \text { to mud flats and } \\
35 \mathrm{~m} \text { to a small tidal inlet. Dominated by mud ark and including club shell } \\
\text { and oyster to a depth of } 5 \mathrm{~cm} \text { determined by auger. Recent excavations } \\
\text { conducted in this general site complex have yielded dates on charcoal up to } \\
700 \pm 140 \text { BP (Wk-6993). References: Burke (1993); Lilley et al. (1997); } \\
\text { Ulm (1999). }\end{array}$ \\
\hline $\mathrm{KE}: \mathrm{A} 45$ & $\begin{array}{l}\text { Shell } \\
\text { Midden/ } \\
\text { Artefact } \\
\text { Scatter }\end{array}$ & $\begin{array}{l}\text { C. Burke } \\
9.3 .93\end{array}$ & $\begin{array}{l}24^{\circ} 02^{\prime} 21^{\prime \prime} \\
151^{\circ} 42^{\prime} 50^{\prime \prime}\end{array}$ & $\begin{array}{l}\text { A stratified linear shell midden }\left(\mathrm{c} .5,500 \mathrm{~m}^{2}\right) \text { located } 50 \mathrm{~m} \text { from the sea } 5- \\
10 \mathrm{~cm} \text { deep and a shell scatter located } 20-30 \mathrm{~m} \text { away from a small tidal inlet } \\
\text { and beach flats on the north bank of Pancake Creek. Dominated by mud ark } \\
\text { and including oyster and club shell, with a single stone artefact noted. } \\
\text { Recent excavations conducted in this general site complex have yielded } \\
\text { dates on charcoal up to } 700 \pm 140 \text { BP(Wk-6993). References: Burke (1993); } \\
\text { Lilley et al. (1997); Ulm (1999). }\end{array}$ \\
\hline KE:A46 & $\begin{array}{l}\text { Shell } \\
\text { Midden }\end{array}$ & $\begin{array}{l}\text { C. Burke } \\
9.3 .93\end{array}$ & $\begin{array}{l}24^{\circ} 02^{\prime} 16^{\prime \prime} \\
151^{\circ} 43^{\prime} 03^{\prime \prime}\end{array}$ & $\begin{array}{l}\text { A linear stratified midden }\left(\mathrm{c} .7,140 \mathrm{~m}^{2}\right) \text { eroding from a creek bank } 20 \mathrm{~m} \text { west } \\
\text { of a tidal inlet on the north bank of Pancake Creek. Shell lens is visible in } \\
\text { the eroding profile for } 238 \mathrm{~m} \text { and continues as a scatter on top of the dune for } \\
\text { another } 97 \mathrm{~m} \text {. Dominated by oyster and includes mud ark, club shell and } \\
\text { charcoal. Recent excavations conducted in this general site complex have } \\
\text { yielded dates on charcoal up to700 } 140 \text { BP (Wk-6993). References: Burke } \\
\text { (1993); Lilley et al. (1997); Ulm (1999). }\end{array}$ \\
\hline $\mathrm{KE}: \mathrm{A} 47$ & $\begin{array}{l}\text { Shell } \\
\text { Midden }\end{array}$ & $\begin{array}{l}\text { C. Burke } \\
9.3 .93\end{array}$ & $\begin{array}{l}24^{\circ} 02^{\prime} 05^{\prime \prime} \\
151^{\circ} 43^{\prime} 15^{\prime \prime}\end{array}$ & $\begin{array}{l}\text { Surface shell scatter }\left(\mathrm{c} .350 \mathrm{~m}^{2}\right) \text { on top of a beach ridge, } 30 \mathrm{~m} \text { from mangroves } \\
\text { and } 15-20 \mathrm{~m} \text { from high water mark on the north bank of Pancake Creek. } \\
\text { Includes oyster, mud ark and thaid. Poor visibility. Recent excavations } \\
\text { conducted in this general site complex have yielded dates on charcoal up to } \\
700 \pm 140 \mathrm{BP} \text { (Wk-6993). References: Burke (1993); Lilley et al. (1997); } \\
\text { Ulm (1999). }\end{array}$ \\
\hline KE:A48 & $\begin{array}{l}\text { Shell } \\
\text { Midden }\end{array}$ & $\begin{array}{l}\text { C. Burke } \\
9.3 .93\end{array}$ & $\begin{array}{l}24^{\circ} 02^{\prime} 25^{\prime \prime} \\
151^{\circ} 42^{\prime} 50^{\prime \prime}\end{array}$ & $\begin{array}{l}\text { Surface shell scatter }\left(c .1,200 \mathrm{~m}^{2}\right) \text { in front of a tidal inlet before mud flats at } \\
\text { a shack, } 100 \mathrm{~m} \text { from the north shore of Pancake Creek. Includes oyster, mud } \\
\text { ark and club shell. Recent excavations conducted in this general site } \\
\text { complex have yielded dates on charcoal up to } 700 \pm 140 \mathrm{BP} \text { (Wk-6993). } \\
\text { References: Burke (1993); Lilley et al. (1997); Ulm (1999). }\end{array}$ \\
\hline KE:A49 & $\begin{array}{l}\text { Shell } \\
\text { Midden }\end{array}$ & $\begin{array}{l}\text { C. Burke } \\
25.3 .93\end{array}$ & $\begin{array}{l}24^{\circ} 11^{\prime} 54^{\prime \prime} \\
151^{\circ} 51^{\prime} 33^{\prime \prime}\end{array}$ & $\begin{array}{l}\text { Three surface shell scatters }\left(\mathrm{c} .1,000 \mathrm{~m}^{2}\right) \text { located on the eroding west bank of } \\
\text { Round Hill Creek. Includes oyster, mud ark and club shell. Excavations } \\
\text { conducted in this general site complex have yielded dates on charcoal up to } \\
3,020 \pm 70 \mathrm{BP} \text { (Wk-3945). References: Burke (1993); Godwin (1990); } \\
\text { Lilley et al. (1996); Lilley et al. (1997); Ulm et al. (this volume). }\end{array}$ \\
\hline KE:A50 & $\begin{array}{l}\text { Shell } \\
\text { Midden }\end{array}$ & $\begin{array}{l}\text { C. Burke } \\
25.3 .93\end{array}$ & $\begin{array}{l}24^{\circ} 11^{\prime} 44^{\prime \prime} \\
151^{\circ} 51^{\prime} 40^{\prime \prime}\end{array}$ & $\begin{array}{l}\text { One linear stratified midden }\left(\mathrm{c} .100 \mathrm{~m}^{2}\right) \text { exposed } 5-10 \mathrm{~cm} \text { deep and two } \\
\text { surface shell scatters }\left(\mathrm{c} .100 \mathrm{~m}^{2}\right) \text { located on the eroding west bank of Round } \\
\text { Hill Creek. Some shell is eroding out of bank. Includes oyster and mud ark. } \\
\text { Excavations conducted in this general site complex have yielded dates on } \\
\text { charcoal up to } 3,020 \pm 70 \mathrm{BP}(\mathrm{Wk}-3945) \text {. References: Burke (1993); } \\
\text { Godwin (1990); Lilley et al. (1996); Lilley et al. (1997); Ulm et al. (this } \\
\text { volume). }\end{array}$ \\
\hline KE:A51 & $\begin{array}{l}\text { Shell } \\
\text { Midden }\end{array}$ & $\begin{array}{l}\text { C. Burke } \\
25.3 .93\end{array}$ & $\begin{array}{l}24^{\circ} 11^{\prime} 35^{\prime \prime} \\
151^{\circ} 51^{\prime} 42^{\prime \prime}\end{array}$ & $\begin{array}{l}\text { Two shell scatters }\left(\mathrm{c} .200 \mathrm{~m}^{2} \text { ) on the west bank of Round Hill Creek exposed }\right. \\
\text { on the surface and up to } 30 \mathrm{~cm} \text { deep in the erosion section. Dense in situ } \\
\text { deposit of mud ark and oyster. Excavations conducted in this general site } \\
\text { complex have yielded dates on charcoal up to } 3,020 \pm 70 \text { BP (Wk-3945). } \\
\text { References: Burke (1993); Godwin (1990); Lilley et al. (1996); Lilley et al. } \\
\text { (1997); Ulm et al. (this volume). }\end{array}$ \\
\hline KE:A52 & $\begin{array}{l}\text { Shell } \\
\text { Midden }\end{array}$ & $\begin{array}{l}\text { C. Burke } \\
25.3 .93\end{array}$ & $\begin{array}{l}24^{\circ} 11^{\prime} 28^{\prime \prime} \\
151^{\circ} 51^{\prime} 45^{\prime \prime}\end{array}$ & $\begin{array}{l}\text { Six shell scatters }\left(\mathrm{c} .2,000 \mathrm{~m}^{2}\right) \text {, including linear stratified deposits up to } 10 \mathrm{~cm} \\
\text { deep, on the west bank of Round Hill Creek. Dominated by mud ark with } \\
\text { some shell eroding out of section, up to } 5 \mathrm{~cm} \text { deep. Excavations conducted } \\
\text { in this general site complex have yielded dates on charcoal up to } 3,020 \pm 70 \\
\text { BP (Wk-3945). References: Burke (1993); Godwin (1990); Lilley et al. } \\
\text { (1996); Lilley et al. (1997); Ulm et al. (this volume). }\end{array}$ \\
\hline
\end{tabular}




\begin{tabular}{|c|c|c|c|c|}
\hline Site ID & Site Type & Recorder & Location & Description \\
\hline KE:A53 & $\begin{array}{l}\text { Shell } \\
\text { Midden }\end{array}$ & $\begin{array}{l}\text { C. Burke } \\
26.3 .93\end{array}$ & $\begin{array}{l}24^{\circ} 11^{\prime} 04^{\prime \prime} \\
151^{\circ} 51^{\prime} 56^{\prime \prime}\end{array}$ & $\begin{array}{l}\text { Three surface shell scatters }\left(\mathrm{c} .450 \mathrm{~m}^{2}\right) \text { on top of a sand ridge adjacent to } \\
\text { Round Hill Creek. Dominated by mud ark with a single large core of granite- } \\
\text { like material noted. Excavations conducted in this general site complex have } \\
\text { yielded dates on charcoal up to } 3,020 \pm 70 \mathrm{BP} \text { (Wk-3945). References: } \\
\text { Burke (1993); Godwin (1990); Lilley et al. (1996); Lilley et al. (1997); Ulm } \\
\text { et al. (this volume). }\end{array}$ \\
\hline KE:A54 & $\begin{array}{l}\text { Shell } \\
\text { Midden }\end{array}$ & $\begin{array}{l}\text { C. Burke } \\
26.3 .93\end{array}$ & $\begin{array}{l}24^{\circ} 10^{\prime} 56^{\prime \prime} \\
151^{\circ} 51^{\prime} 50^{\prime \prime}\end{array}$ & $\begin{array}{l}\text { Two surface shell scatters on top of a sand ridge and on a tidal flat } \\
\left.\text { (c. } 700 \mathrm{~m}^{2}\right) \text {, and a linear stratified deposit }\left(\mathrm{c} .750 \mathrm{~m}^{2}\right) \text { on a sand ridge adjacent } \\
\text { to Round Hill Creek. Dominated by mud ark and including oyster. } \\
\text { Excavations conducted in this general site complex have yielded dates on } \\
\text { charcoal up to } 3,020 \pm 70 \mathrm{BP}(\mathrm{Wk}-3945) \text {. References: Burke (1993); } \\
\text { Godwin (1990); Lilley et al. (1996); Lilley et al. (1997); Ulm et al. (this } \\
\text { volume). }\end{array}$ \\
\hline $\mathrm{KE}: \mathrm{A} 55$ & $\begin{array}{l}\text { Shell } \\
\text { Midden/ } \\
\text { Artefact } \\
\text { Scatter }\end{array}$ & $\begin{array}{l}\text { C. Burke } \\
1.6 .93\end{array}$ & $\begin{array}{l}24^{\circ} 01^{\prime} 00^{\prime \prime} \\
151^{\circ} 45^{\prime} 46^{\prime \prime}\end{array}$ & $\begin{array}{l}\text { Sparse scatter of oyster shell including } 7 \text { stone artefacts }\left(c .400 \mathrm{~m}^{2}\right) \text {, located } \\
\text { on the north side of Bustard Head. Raw materials may not be local. } \\
\text { References: Burke (1993). }\end{array}$ \\
\hline KE:A56 & $\begin{array}{l}\text { Shell } \\
\text { Midden }\end{array}$ & $\begin{array}{l}\text { C. Burke } \\
21.4 .93\end{array}$ & $\begin{array}{l}24^{\circ} 02^{\prime} 31^{\prime \prime} \\
151^{\circ} 33^{\prime} 54^{\prime \prime}\end{array}$ & $\begin{array}{l}\text { Low density surface shell scatter }\left(\mathrm{c} .70 \mathrm{~m}^{2}\right) \text { located in an open, gently sloping } \\
\text { area } 10 \mathrm{~m} \text { from the beach on the west side of Innes Head, on the east bank of } \\
\text { Seven Mile Creek. Dominated by oyster and includes mussel. References: } \\
\text { Burke (1993). }\end{array}$ \\
\hline KE:A57 & $\begin{array}{l}\text { Shell } \\
\text { Midden/ } \\
\text { Artefact } \\
\text { Scatter }\end{array}$ & $\begin{array}{l}\text { C. Burke } \\
22.4 .93\end{array}$ & $\begin{array}{l}24^{\circ} 05^{\prime} 10^{\prime \prime} \\
151^{\circ} 38^{\prime} 52^{\prime \prime}\end{array}$ & $\begin{array}{l}\text { Three small surface shell scatters }\left(c .70 \mathrm{~m}^{2}\right) \text { located on and around a graded } \\
\text { dirt road c. } 50 \mathrm{~m} \text { from mangroves, on the east edge of an unnamed } \\
\text { embayment on the west side of the Turkey Beach peninsula. Dominated by } \\
\text { mud ark and including oyster and a single white quartz flaked piece. } \\
\text { References: Burke (1993). }\end{array}$ \\
\hline KE:A58 & $\begin{array}{l}\text { Artefact } \\
\text { Scatter }\end{array}$ & $\begin{array}{l}\text { C. Burke } \\
22.4 .93\end{array}$ & $\begin{array}{l}24^{\circ} 05^{\prime} 44^{\prime \prime} \\
151^{\circ} 38^{\prime} 10^{\prime \prime}\end{array}$ & $\begin{array}{l}\text { Isolated stone artefact manufactured on banded chert located on mud flats } \\
\text { on the east edge of an unnamed embayment on the west side of the Turkey } \\
\text { Beach peninsula, c. } 50 \mathrm{~m} \text { from mangroves. References: Burke (1993). }\end{array}$ \\
\hline $\mathrm{KE}: \mathrm{A} 59$ & $\begin{array}{l}\text { Shell } \\
\text { Midden/ } \\
\text { Artefact } \\
\text { Scatter }\end{array}$ & $\begin{array}{l}\text { C. Burke } \\
1.6 .93\end{array}$ & $\begin{array}{l}24^{\circ} 01^{\prime} 56^{\prime \prime} \\
151^{\circ} 44^{\prime} 40^{\prime \prime}\end{array}$ & $\begin{array}{l}\text { Very sparse surface shell scatter }\left(c .24,000 \mathrm{~m}^{2}\right) \text {, including one quartz flaked } \\
\text { piece, located on the edge of mud flats on the Jenny Lind Creek side of } \\
\text { Bustard Head. Dominated by mud ark and oyster and including club shell. } \\
\text { References: Burke (1993). }\end{array}$ \\
\hline KE:A60 & $\begin{array}{l}\text { Scarred } \\
\text { Tree }\end{array}$ & $\begin{array}{l}\text { C. Burke } \\
30.4 .93\end{array}$ & $\begin{array}{l}24^{\circ} 12^{\prime} 51^{\prime \prime} \\
151^{\circ} 54^{\prime} 16^{\prime \prime}\end{array}$ & $\begin{array}{l}\text { Scarred tree located in the centre of Agnes Water. Scar is located on a large } \\
\text { eucalyptus tree (Queensland blue gum or Moreton Bay ash). Scar measures } \\
250 \mathrm{~cm} \text { x } 46 \mathrm{~cm} \text {. References: Burke (1993); Lilley et al. (1997). }\end{array}$ \\
\hline KE:A61 & $\begin{array}{l}\text { Shell } \\
\text { Midden }\end{array}$ & $\begin{array}{l}\text { C. Burke } \\
17.5 .93\end{array}$ & $\begin{array}{l}24^{\circ} 01^{\prime} 56^{\prime \prime} \\
151^{\circ} 44^{\prime} 40^{\prime \prime}\end{array}$ & $\begin{array}{l}\text { Fairly dense discrete stratified shell midden with depth of } 10 \mathrm{~cm} \text {, located on } \\
\text { the east bank of Round Hill Creek, c. } 100 \mathrm{~m} \text { from KE:A16. Dominated by } \\
\text { mud ark. Site damaged by bulldozer activity. References: Burke (1993); } \\
\text { Lilley et al. (1997). }\end{array}$ \\
\hline KE:A62 & $\begin{array}{l}\text { Shell } \\
\text { Midden/ } \\
\text { Artefact } \\
\text { Scatter }\end{array}$ & $\begin{array}{l}\text { C. Burke } \\
22.5 .93\end{array}$ & $\begin{array}{l}24^{\circ} 10^{\prime} 57^{\prime \prime} \\
151^{\circ} 52^{\prime} 53^{\prime \prime}\end{array}$ & $\begin{array}{l}\text { Linear stratified midden }\left(\mathrm{c} .4,200 \mathrm{~m}^{2}\right) \text { with in situ lens of shell } \mathrm{c} .50 \mathrm{~cm} \text { below } \\
\text { ground surface and up to } 10 \mathrm{~cm} \text { thick. Subsurface material exposed in a large } \\
\text { excavation behind the sewage treatment depot. Dominated by mud ark and } \\
\text { including oyster and stone artefacts manufactured on a variety of raw } \\
\text { materials. This site is probably part of the more extensive KE:A11 (see } \\
\text { above). References: Burke (1993). }\end{array}$ \\
\hline $\mathrm{KE}: \mathrm{A} 63$ & $\begin{array}{l}\text { Shell } \\
\text { Midden }\end{array}$ & $\begin{array}{l}\text { C. Burke } \\
22.5 .93\end{array}$ & $\begin{array}{l}24^{\circ} 11^{\prime} 10^{\prime \prime} \\
151^{\circ} 52^{\prime} 33^{\prime \prime}\end{array}$ & $\begin{array}{l}\text { Very sparse surface scatter }\left(\mathrm{c} .400 \mathrm{~m}^{2}\right) \text { of mud ark and oyster shell located on } \\
\text { either side of a } 4 \text { WD track. This site is probably part of the more extensive } \\
\text { KE:A11 (see above). References: Burke (1993). }\end{array}$ \\
\hline KE:A64 & $\begin{array}{l}\text { Shell } \\
\text { Midden/ } \\
\text { Artefact } \\
\text { Scatter }\end{array}$ & $\begin{array}{l}\text { I. Lilley } \\
\text { 10-14.4.94 }\end{array}$ & $\begin{array}{l}24^{\circ} 04^{\prime} 10^{\prime \prime} \\
151^{\circ} 43^{\prime} 35^{\prime \prime}\end{array}$ & $\begin{array}{l}\text { Shell midden complex }\left(\mathrm{c} .200,000 \mathrm{~m}^{2}\right) \text { up to } 15 \mathrm{~cm} \text { deep on the central west } \\
\text { coast of Middle Island. Dominated by mud ark and including oyster and a } \\
\text { quartz flake. Located in low swampy melaleuca shrubland adjacent to mud } \\
\text { flats on a tidal creek. References: Lilley (1994). }\end{array}$ \\
\hline $\mathrm{KE}: \mathrm{A} 65$ & $\begin{array}{l}\text { Shell } \\
\text { Midden }\end{array}$ & $\begin{array}{l}\text { I. Lilley } \\
\text { 10-14.4.94 }\end{array}$ & $\begin{array}{l}24^{\circ} 05^{\prime} 30^{\prime \prime} \\
151^{\circ} 45^{\prime} 00^{\prime \prime}\end{array}$ & $\begin{array}{l}\text { Shell midden complex }\left(c .800,000 \mathrm{~m}^{2}\right) \text { located on high north-south trending } \\
\text { dunes extending for c. } 7 \mathrm{~km} \text { along the central western side of Middle Island. } \\
\text { Comprises mud ark, oyster, pipi and club shell. References: Lilley (1994). }\end{array}$ \\
\hline
\end{tabular}




\begin{tabular}{|c|c|c|c|c|}
\hline Site ID & Site Type & Recorder & Location & Description \\
\hline $\mathrm{KE}: \mathrm{A} 66$ & $\begin{array}{l}\text { Shell } \\
\text { Midden/ } \\
\text { Artefact } \\
\text { Scatter }\end{array}$ & $\begin{array}{l}\text { I. Lilley } \\
\text { 10-14.4.94 }\end{array}$ & $\begin{array}{l}24^{\circ} 06^{\prime} 00^{\prime \prime} \\
151^{\circ} 44^{\prime} 30^{\prime \prime}\end{array}$ & $\begin{array}{l}\left.\text { Shell midden complex (c. } 800,000 \mathrm{~m}^{2}\right) \text { located on high north-south trending } \\
\text { dunes extending for c.5km along the central eastern side of Middle Island. } \\
\text { Comprises mud ark, oyster and pipi as well as a quartz core. References: } \\
\text { Lilley (1994). }\end{array}$ \\
\hline KE:A67 & $\begin{array}{l}\text { Shell } \\
\text { Midden }\end{array}$ & $\begin{array}{l}\text { I. Lilley } \\
\text { 10-14.4.94 }\end{array}$ & $\begin{array}{l}24^{\circ} 03^{\prime} 44^{\prime \prime} \\
151^{\circ} 45^{\prime} 56^{\prime \prime}\end{array}$ & $\begin{array}{l}\text { Shell midden complex }\left(\mathrm{c} .140,000 \mathrm{~m}^{2}\right) \text { dominated by pipi up to } 15 \mathrm{~cm} \text { deep on } \\
\text { parabolic dunes and sandblows on the northeast end of Middle Island, } \\
\text { bordered in the north and west by Jenny Lind Creek. Recent excavations in } \\
\text { this general site complex have yielded dates on shell up to } 980 \pm 50 \mathrm{BP} \\
\text { (Wk-7679). References: Lilley (1994); Lilley et al. (1997); Ulm (1999). }\end{array}$ \\
\hline $\mathrm{KF}: \mathrm{A} 01$ & $\begin{array}{l}\text { Shell } \\
\text { Midden }\end{array}$ & $\begin{array}{l}\text { C. Burke } \\
6.3 .93\end{array}$ & $\begin{array}{l}23^{\circ} 58^{\prime} 52^{\prime \prime} \\
151^{\circ} 36^{\prime} 48^{\prime \prime}\end{array}$ & $\begin{array}{l}\text { Very sparse surface shell scatter dominated by oyster on the east side of } \\
\text { Richards Point, Rodds Peninsula. Total of } 20 \text { fragments. MNI=6-10. } \\
\text { References: Burke (1993). }\end{array}$ \\
\hline $\mathrm{KF}: \mathrm{A} 02$ & $\begin{array}{l}\text { Shell } \\
\text { Midden }\end{array}$ & $\begin{array}{l}\text { C. Burke } \\
7-8.3 .93\end{array}$ & $\begin{array}{l}23^{\circ} 59^{\prime} 20^{\prime \prime} \\
151^{\circ} 40^{\prime} 06^{\prime \prime}\end{array}$ & $\begin{array}{l}\text { Four low density shell scatters }\left(\mathrm{c} .1,200 \mathrm{~m}^{2}\right) \text { up to } 5 \mathrm{~cm} \text { deep dominated by } \\
\text { oyster but also including chiton, austros, turbos and mud ark, located on the } \\
\text { northeast coast of Rodds Peninsula. Scatters in close proximity to beach, } \\
\text { tidal inlet and rock platforms. References: Burke (1993). }\end{array}$ \\
\hline $\mathrm{KF}: \mathrm{A} 03$ & $\begin{array}{l}\text { Shell } \\
\text { Midden }\end{array}$ & $\begin{array}{l}\text { C. Burke } \\
8.3 .93\end{array}$ & $\begin{array}{l}23^{\circ} 59^{\prime} 23^{\prime \prime} \\
151^{\circ} 39^{\prime} 44^{\prime \prime}\end{array}$ & $\begin{array}{l}\text { Two surface shell scatters }\left(\mathrm{c} .1,400 \mathrm{~m}^{2}\right) \text { located behind dunes and a tidal inlet } \\
50-60 \mathrm{~m} \text { from ocean and rock platforms, located on the northeast coast of } \\
\text { Rodds Peninsula. Dominated by oyster and including mud ark, chiton and } \\
\text { turbo. References: Burke (1993). }\end{array}$ \\
\hline $\mathrm{KF}: \mathrm{A04}$ & $\begin{array}{l}\text { Shell } \\
\text { Midden }\end{array}$ & $\begin{array}{l}\text { C. Burke } \\
8.3 .93\end{array}$ & $\begin{array}{l}23^{\circ} 59^{\prime} 13^{\prime \prime} \\
151^{\circ} 39^{\prime} 29^{\prime \prime}\end{array}$ & $\begin{array}{l}\text { Very sparse surface shell scatter }\left(c .40 \mathrm{~m}^{2}\right) \text { of oyster } 20 \mathrm{~m} \text { from beach and rock } \\
\text { platforms, located on the northeast coast of Rodds Peninsula, c. } 10 \text { masl. Site } \\
\text { is behind thick scrub. References: Burke (1993). }\end{array}$ \\
\hline $\mathrm{KF}: \mathrm{A05}$ & $\begin{array}{l}\text { Shell } \\
\text { Midden }\end{array}$ & $\begin{array}{l}\text { C. Burke } \\
8.3 .93\end{array}$ & $\begin{array}{l}23^{\circ} 59^{\prime} 05^{\prime \prime} \\
151^{\circ} 39^{\prime} 22^{\prime \prime}\end{array}$ & $\begin{array}{l}\text { Two shell scatters }\left(\mathrm{c} .1,700 \mathrm{~m}^{2}\right) \text { at least } 15 \mathrm{~cm} \text { deep situated on a bank near the } \\
\text { beach c. } 20 \mathrm{~m} \text { from the sea and rock platforms, located on the northeast coast } \\
\text { of Rodds Peninsula. Dominated by oyster and including mud ark, chiton and } \\
\text { turbos. References: Burke (1993). }\end{array}$ \\
\hline $\mathrm{KF}: \mathrm{A} 06$ & $\begin{array}{l}\text { Shell } \\
\text { Midden }\end{array}$ & $\begin{array}{l}\text { C. Burke } \\
8.3 .93\end{array}$ & $\begin{array}{l}23^{\circ} 59^{\prime} 27^{\prime \prime} \\
151^{\circ} 40^{\prime} 14^{\prime \prime}\end{array}$ & $\begin{array}{l}\text { Two sparse oyster scatters }\left(\mathrm{c} .150 \mathrm{~m}^{2}\right) \text { located } 50 \mathrm{~m} \text { from beach and rocks, } \\
\text { located in the vicinity of foredunes on the northeast coast of Rodds } \\
\text { Peninsula. Freshwater creeks in close vicinity to deposits. References: Burke } \\
\text { (1993). }\end{array}$ \\
\hline KF:A07 & $\begin{array}{l}\text { Shell } \\
\text { Midden }\end{array}$ & $\begin{array}{l}\text { C. Burke } \\
9.3 .93\end{array}$ & $\begin{array}{l}23^{\circ} 58^{\prime} 52^{\prime \prime} \\
151^{\circ} 38^{\prime} 52^{\prime \prime}\end{array}$ & $\begin{array}{l}\text { Sparse oyster deposits }\left(\mathrm{c} .200 \mathrm{~m}^{2}\right) \text { up to } 5 \mathrm{~cm} \text { deep situated } \mathrm{c} .100 \mathrm{~m} \text { from sea } \\
\text { and } 5 \text { masl on a bank on top of a ridge, located on the northeast coast of } \\
\text { Rodds Peninsula. Dominated by oyster and including austro. References: } \\
\text { Burke (1993). }\end{array}$ \\
\hline KF:A08 & $\begin{array}{l}\text { Artefact } \\
\text { Scatter }\end{array}$ & $\begin{array}{l}\text { C. Burke } \\
9.3 .93\end{array}$ & $\begin{array}{l}23^{\circ} 58^{\prime} 33^{\prime \prime} \\
151^{\circ} 37^{\prime} 31^{\prime \prime}\end{array}$ & $\begin{array}{l}\text { Isolated stone artefact on a steep rocky slope on top of a headland on the east } \\
\text { side of Richards Point, Rodds Peninsula, c.20masl and } 20 \mathrm{~m} \text { from rock } \\
\text { platforms and ocean. References: Burke (1993). }\end{array}$ \\
\hline KF:A09 & $\begin{array}{l}\text { Shell } \\
\text { Midden }\end{array}$ & $\begin{array}{l}\text { C. Burke } \\
9.3 .93\end{array}$ & $\begin{array}{l}23^{\circ} 58^{\prime} 45^{\prime \prime} \\
151^{\circ} 37^{\prime} 44^{\prime \prime}\end{array}$ & $\begin{array}{l}\text { Surface shell scatter }\left(\mathrm{c} .200 \mathrm{~m}^{2}\right) \text { on beach } 0.5 \text { masl and } 10 \mathrm{~m} \text { from rock } \\
\text { platforms and ocean, } 500 \mathrm{~m} \text { northwest of Richards Point, Rodds Peninsula. } \\
\text { Dominated by oyster and including mud ark and austros. References: Burke } \\
(1993) \text {. }\end{array}$ \\
\hline $\mathrm{KF}: \mathrm{A} 10$ & $\begin{array}{l}\text { Shell } \\
\text { Midden }\end{array}$ & $\begin{array}{l}\text { C. Burke } \\
9.3 .93\end{array}$ & $\begin{array}{l}23^{\circ} 58^{\prime} 45^{\prime \prime} \\
151^{\circ} 37^{\prime} 44^{\prime \prime}\end{array}$ & $\begin{array}{l}\text { Surface oyster scatter }\left(\mathrm{c} .800 \mathrm{~m}^{2}\right) \text { at least } 5 \mathrm{~cm} \text { deep situated } 50 \mathrm{~m} \text { from beach } \\
\text { in open woodland, located on the northeast coast of Rodds Peninsula. Ocean } \\
\text { and rock platforms } 200 \mathrm{~m} \text { from site. Augering revealed shell to } 5 \mathrm{~cm} \text { in depth. } \\
\text { References: Burke (1993). }\end{array}$ \\
\hline KF:Al1 & $\begin{array}{l}\text { Shell } \\
\text { Midden }\end{array}$ & $\begin{array}{l}\text { C. Burke } \\
9.3 .93\end{array}$ & $\begin{array}{l}23^{\circ} 58^{\prime} 51^{\prime \prime} \\
151^{\circ} 37^{\prime} 18^{\prime \prime}\end{array}$ & $\begin{array}{l}\text { Sparse surface scatters }\left(\mathrm{c} .500 \mathrm{~m}^{2}\right) \text { of oyster and mud ark, } 50-100 \mathrm{~m} \text { from rock } \\
\text { platforms and ocean, located on the northeast coast of Rodds Peninsula. } \\
\text { Tidal creek in close vicinity. References: Burke (1993). }\end{array}$ \\
\hline KF:A12 & $\begin{array}{l}\text { Fish } \\
\text { Trap }\end{array}$ & $\begin{array}{l}\text { C. Burke } \\
9.3 .93\end{array}$ & $\begin{array}{l}23^{\circ} 58^{\prime} 40^{\prime \prime} \\
151^{\circ} 37^{\prime} 25^{\prime \prime}\end{array}$ & $\begin{array}{l}\text { Stone-walled fish trap of unknown dimensions located in a small bay to the } \\
\text { immediate west of Richards Point. The trap appears to contain water at both } \\
\text { high and low tide. The trap is in the shape of an arc with a formed opening } \\
\text { in the centre of it. References: Burke (1993); Lilley et al. (1997). }\end{array}$ \\
\hline
\end{tabular}




\begin{tabular}{|c|c|c|c|c|}
\hline Site ID & Site Type & Recorder & Location & Description \\
\hline $\mathrm{KF}: \mathrm{A} 13$ & $\begin{array}{l}\text { Shell } \\
\text { Midden }\end{array}$ & $\begin{array}{l}\text { C. Burke } \\
8.3 .93\end{array}$ & $\begin{array}{l}23^{\circ} 59^{\prime} 24^{\prime \prime} \\
151^{\circ} 40^{\prime} 13^{\prime \prime}\end{array}$ & $\begin{array}{l}\text { Very sparse surface shell scatters }\left(c .50 \mathrm{~m}^{2}\right) \text {, mostly oyster, c. } 20-50 \mathrm{~m} \text { from } \\
\text { rock platforms and ocean. Freshwater creek located } 10-50 \mathrm{~m} \text { away. } \\
\text { References: Burke (1993). }\end{array}$ \\
\hline $\mathrm{KF}: \mathrm{A} 14$ & $\begin{array}{l}\text { Shell } \\
\text { Midden }\end{array}$ & $\begin{array}{l}\text { C. Burke } \\
8.3 .93\end{array}$ & $\begin{array}{l}23^{\circ} 59^{\prime} 08^{\prime \prime} \\
151^{\circ} 39^{\prime} 11^{\prime \prime}\end{array}$ & $\begin{array}{l}\text { Sparse surface shell scatters }\left(c .3,650 \mathrm{~m}^{2}\right) \text { situated on top of a dune ridge in } \\
\text { a clearing behind the beach, located on the northeast coast of Rodds } \\
\text { Peninsula. Dominated by oyster and including mud ark, chiton and mussel. } \\
\text { Tidal creek is located nearby. References: Burke (1993). }\end{array}$ \\
\hline $\mathrm{KF}: \mathrm{A} 15$ & $\begin{array}{l}\text { Shell } \\
\text { Midden }\end{array}$ & $\begin{array}{l}\text { C. Burke } \\
8.3 .93\end{array}$ & $\begin{array}{l}23^{\circ} 59^{\prime} 08^{\prime \prime} \\
151^{\circ} 39^{\prime} 09^{\prime \prime}\end{array}$ & $\begin{array}{l}\text { Sparse surface shell scatter, mostly oyster, situated on top of a dune ridge, } \\
\text { located on the northeast coast of Rodds Peninsula. Tidal creek is located } \\
\text { nearby. References: Burke (1993). }\end{array}$ \\
\hline $\mathrm{KF}: \mathrm{A} 16$ & $\begin{array}{l}\text { Shell } \\
\text { Midden }\end{array}$ & $\begin{array}{l}\text { C. Burke } \\
8.3 .93\end{array}$ & $\begin{array}{l}23^{\circ} 58^{\prime} 55^{\prime \prime} \\
151^{\circ} 38^{\prime} 50^{\prime \prime}\end{array}$ & $\begin{array}{l}\text { Surface oyster scatter }\left(c .25 \mathrm{~m}^{2}\right) \text { situated } c .100 \mathrm{~m} \text { from ocean and } 50 \mathrm{~m} \text { from } \\
\text { rock platforms, 5masl, located on the northeast coast of Rodds Peninsula. } \\
\text { References: Burke (1993). }\end{array}$ \\
\hline SCC10 & $\begin{array}{l}\text { Shell } \\
\text { Midden/ } \\
\text { Artefact } \\
\text { Scatter }\end{array}$ & S. Ulm & $\begin{array}{l}24^{\circ} 11^{\prime} 00^{\prime \prime} \\
151^{\circ} 49^{\prime} 30^{\prime \prime}\end{array}$ & $\begin{array}{l}\text { Extensive surface scatter of shell and stone artefacts visible on Eurimbula } \\
\text { Creek 4WD access track. Bracken fern fringes the track on both sides } \\
\text { making it difficult to determine the extent of the scatter due to lack of } \\
\text { visibility. Includes flakes, flaked pieces, cores and manuports manufactured } \\
\text { on pyroclastic rhyolite, quartz and indurated mudstone. Shell includes mud } \\
\text { ark and oyster. References: Lilley et al. (1997). }\end{array}$ \\
\hline $\mathrm{SCC} 12$ & $\begin{array}{l}\text { Artefact } \\
\text { Scatter }\end{array}$ & S. Ulm & $\begin{array}{l}24^{\circ} 14^{\prime} 30^{\prime \prime} \\
151^{\circ} 56^{\prime} 30^{\prime \prime}\end{array}$ & $\begin{array}{l}\text { Stone artefact scatter on } 4 \text { WD road shoulder on headland. Pyroclastic } \\
\text { rhyolite artefacts found eroding out of a nearby road cutting up to } 60 \mathrm{~cm} \\
\text { below ground surface. Cores, flakes, flaked pieces, grinding stone made on } \\
\text { indurated mudstone, pyroclastic rhyolite, silcrete, quartz and quartzite. Some } \\
\text { retouched artefacts. References: Lilley et al. (1997). }\end{array}$ \\
\hline SCC17 & $\begin{array}{l}\text { Artefact } \\
\text { Scatter }\end{array}$ & S. Ulm & $\begin{array}{l}24^{\circ} 16^{\prime} 00^{\prime \prime} \\
151^{\circ} 56^{\prime} 50^{\prime \prime}\end{array}$ & $\begin{array}{l}\text { Two stone artefacts located on the open coast on the south side of the Red } \\
\text { Rock headland, south of Rocky Point. One broken waterworn pebble } \\
\text { manuport with cortex and one flake on a red igneous rock (silcrete?). } \\
\text { References: Lilley et al. (1997). }\end{array}$ \\
\hline SCC1 8 & $\begin{array}{l}\text { Artefact } \\
\text { Scatter }\end{array}$ & S. Ulm & $\begin{array}{l}24^{\circ} 16^{\prime} 00^{\prime \prime} \\
151^{\circ} 56^{\prime} 50^{\prime \prime}\end{array}$ & $\begin{array}{l}\text { Two pyroclastic rhyolite cores and one andesite flake located on a walking } \\
\text { track on the open coast on the south side of the Red Rock headland, south } \\
\text { of Rocky Point. References: Lilley et al. (1997). }\end{array}$ \\
\hline SCC19 & $\begin{array}{l}\text { Artefact } \\
\text { Scatter }\end{array}$ & S. Ulm & $\begin{array}{l}24^{\circ} 14^{\prime} 00^{\prime \prime} \\
151^{\circ} 56^{\prime} 00^{\prime \prime}\end{array}$ & $\begin{array}{l}\text { Low density scatter of pyroclastic rhyolite flakes and flaked pieces exposed } \\
\text { on eroding walking and vehicle tracks across the northern Rocky Point } \\
\text { headland. References: Lilley et al. (1997). }\end{array}$ \\
\hline $\mathrm{SCC} 21$ & $\begin{array}{l}\text { Artefact } \\
\text { Scatter }\end{array}$ & S. Ulm & $\begin{array}{l}24^{\circ} 14^{\prime} 00^{\prime \prime} \\
151^{\circ} 56^{\prime} 00^{\prime \prime}\end{array}$ & $\begin{array}{l}\text { Scatter of } 20 \text { flakes and flaked pieces manufactured on chert, pyroclastic } \\
\text { rhyolite and quartzite exposed in an eroding road cutting on the northern } \\
\text { Rocky Point headland. References: Lilley et al. (1997). }\end{array}$ \\
\hline SCC26 & $\begin{array}{l}\text { Shell } \\
\text { Midden/ } \\
\text { Artefact } \\
\text { Scatter/ } \\
\text { Stone } \\
\text { Quarry }\end{array}$ & S. Ulm & $\begin{array}{l}24^{\circ} 07^{\prime} 00^{\prime \prime} \\
151^{\circ} 46^{\prime} 30^{\prime \prime}\end{array}$ & $\begin{array}{l}\text { Extensive shell midden and quarry site complex }\left(140,000 \mathrm{~m}^{2}\right) \text { located on the } \\
\text { south bank of Middle Creek close to its mouth. Including oyster, mud ark, } \\
\text { nerite and pipi. Shell material visible in erosion sections up to } 25 \mathrm{~cm} \text { deep. } \\
\text { Extensive outcrop of modified pyroclastic rhyolite. Surface artefact densities } \\
\text { up to } 110 / \mathrm{m}^{2} \text {. Recent excavations have yielded dates on charcoal up to } 1,640 \\
\pm 150 \mathrm{BP} \text { (Wk-6361). References: Lilley et al. (1997); Reid (1998). }\end{array}$ \\
\hline SCC 30 & $\begin{array}{l}\text { Artefact } \\
\text { Scatter }\end{array}$ & S. Ulm & $\begin{array}{l}24^{\circ} 09^{\prime} 00^{\prime \prime} \\
151^{\circ} 46^{\prime} 30^{\prime \prime}\end{array}$ & $\begin{array}{l}\text { Small stone artefact scatter on salt pan at the southern extremities of Middle } \\
\text { Creek estuary where low mangroves begin at base of creek. At least } 10 \\
\text { pyroclastic rhyolite cores and } 2 \text { flakes spread over c. } 200 \mathrm{~m}^{2} \text { area c. } 20 \mathrm{~m} \text { west } \\
\text { of low casuarina fringe. Several isolated fragments of shell noted along } \\
\text { mangrove fringe. References: Lilley et al. (1997). }\end{array}$ \\
\hline SCC 31 & $\begin{array}{l}\text { Artefact } \\
\text { Scatter }\end{array}$ & S. Ulm & $\begin{array}{l}24^{\circ} 08^{\prime} 30^{\prime \prime} \\
151^{\circ} 47^{\prime} 00^{\prime \prime}\end{array}$ & $\begin{array}{l}26 \text { pyroclastic rhyolite artefacts embedded in a muddy surface on mud flats } \\
\text { in the centre of open area on Middle Creek estuary. References: Lilley et al. } \\
\text { (1997). }\end{array}$ \\
\hline SCC 35 & $\begin{array}{l}\text { Artefact } \\
\text { Scatter }\end{array}$ & S. Ulm & $\begin{array}{l}24^{\circ} 09^{\prime} 30^{\prime \prime} \\
151^{\circ} 48^{\prime} 00^{\prime \prime}\end{array}$ & $\begin{array}{l}9 \text { pyroclastic rhyolite artefacts scattered over a } 50 \mathrm{~m}^{2} \text { area c. } 30 \mathrm{~m} \text { southeast } \\
\text { of bridge on saltpan at the northern extremity of Eurimbula Creek. } \\
\text { References: Lilley et al. (1997). }\end{array}$ \\
\hline
\end{tabular}




\begin{tabular}{|c|c|c|c|c|}
\hline Site ID & Site Type & Recorder & Location & Description \\
\hline SCC 36 & $\begin{array}{l}\text { Shell } \\
\text { Midden/ } \\
\text { Artefact } \\
\text { Scatter }\end{array}$ & S. Ulm & $\begin{array}{l}24^{\circ} 09^{\prime} 40^{\prime \prime} \\
151^{\circ} 48^{\prime} 10^{\prime \prime}\end{array}$ & $\begin{array}{l}\text { Low density scatter of oyster shell fragments and two water-worn manuports } \\
\text { visible on bank about } 10 \mathrm{~m} \text { through mangroves to channel of Eurimbula } \\
\text { Creek. References: Lilley et al. (1997). }\end{array}$ \\
\hline SCC37 & $\begin{array}{l}\text { Shell } \\
\text { Midden }\end{array}$ & S. Ulm & $\begin{array}{l}24^{\circ} 09^{\prime} 54^{\prime \prime} \\
151^{\circ} 49^{\prime} 02^{\prime \prime}\end{array}$ & $\begin{array}{l}\text { Scatter of midden shell visible in low }(\mathrm{c} .30 \mathrm{~cm} \text { high) erosion bank on } \\
\text { mangrove fringe of Eurimbula Creek. Some sparse scattered oyster } \\
\text { fragments visible on surface. Main scatter c. } 5 \mathrm{~m}^{2} \text { eroding out of bank onto } \\
\text { flat mangrove fringe. Shell lens visible in erosion bank c. } 18 \mathrm{~cm} \text { below } \\
\text { surface and c. } 3 \mathrm{~cm} \text { thick for c. } 3 \mathrm{~m} \text { along bank. Density }=\mathrm{c} .108 / \mathrm{m}^{2} \text {. Includes } \\
\text { oyster and mud ark. Recent excavations in this general site complex have } \\
\text { yielded a date on charcoal of } 230 \pm 60 \mathrm{BP}(\mathrm{Wk}-7680 \text { ). References: Lilley et } \\
\text { al. (1997); Ulm (1999). }\end{array}$ \\
\hline SCC38 & $\begin{array}{l}\text { Shell } \\
\text { Midden }\end{array}$ & S. Ulm & $\begin{array}{l}24^{\circ} 10^{\prime} 04^{\prime \prime} \\
151^{\circ} 49^{\prime} 22^{\prime \prime}\end{array}$ & $\begin{array}{l}\text { Scatter of shell visible on top of a low dune c. } 20 \mathrm{~m} \text { northeast of mangrove } \\
\text { fringe of Eurimbula Creek mainly visible in the burrow of unknown animal. } \\
\text { Scatter spread over an area of c. } 10 \mathrm{~m}^{2} \text {. Max. Density }=25 / \mathrm{m}^{2} \text {. Predominantly } \\
\text { oyster, with some nerites, mud ark, whelk and telescopium. Located in dry } \\
\text { rainforest thicket. Recent excavations in this general site complex have } \\
\text { yielded modern radiocarbon dates. References: Lilley et al. (1997); Ulm } \\
\text { (1999). }\end{array}$ \\
\hline SCC 39 & $\begin{array}{l}\text { Shell } \\
\text { Midden/ } \\
\text { Artefact } \\
\text { Scatter }\end{array}$ & S. UIm & $\begin{array}{l}24^{\circ} 10^{\prime} 10^{\prime \prime} \\
151^{\circ} 49^{\prime} 36^{\prime \prime}\end{array}$ & $\begin{array}{l}\text { Very sparse scatter of shell visible on low (c. } 1 \mathrm{~m} \text { high) erosion bank c. } 10 \mathrm{~m} \\
\text { north of Eurimbula Creek. Includes mud ark, oyster and club shell as well } \\
\text { as several flaked pieces of quartz and pyroclastic rhyolite and some larger, } \\
\text { possibly ground, implements manufactured on the latter. References: Lilley } \\
\text { et al. (1997). }\end{array}$ \\
\hline SCC48 & $\begin{array}{l}\text { Shell } \\
\text { Midden }\end{array}$ & S. Ulm & $\begin{array}{l}24^{\circ} 11^{\prime} 50^{\prime \prime} \\
151^{\circ} 52^{\prime} 10^{\prime \prime}\end{array}$ & $\begin{array}{l}\text { Mounded mud ark midden disturbed by bush turkey nesting activity located } \\
\text { near the eastern bank of Round Hill Creek and south bank of Tom's Creek, } \\
\text { Agnes Water. References: Lilley et al. (1997). }\end{array}$ \\
\hline SCC50 & $\begin{array}{l}\text { Scarred } \\
\text { Tree }\end{array}$ & S. Ulm & $\begin{array}{l}24^{\circ} 15^{\prime} 30^{\prime \prime} \\
151^{\circ} 53^{\prime} 00^{\prime \prime}\end{array}$ & $\begin{array}{l}\text { Possible scarred tree which has been felled for construction of a power } \\
\text { easement on the southern margin of Round Hill National Park. References: } \\
\text { Lilley et al. (1997). }\end{array}$ \\
\hline SCC51 & $\begin{array}{l}\text { Artefact } \\
\text { Scatter }\end{array}$ & S. Ulm & $\begin{array}{l}24^{\circ} 15^{\prime} 00^{\prime \prime} \\
151^{\circ} 55^{\prime} 30^{\prime \prime}\end{array}$ & $\begin{array}{l}\text { Low density scatter of stone artefacts located along the northeast margin of } \\
\text { Deepwater swamp, southwest of Rocky Point. References: Lilley et al. } \\
\text { (1997). }\end{array}$ \\
\hline SCC55 & $\begin{array}{l}\text { Shell } \\
\text { Midden }\end{array}$ & S. Ulm & $\begin{array}{l}24^{\circ} 04^{\prime} 30^{\prime \prime} \\
151^{\circ} 39^{\prime} 00^{\prime \prime}\end{array}$ & $\begin{array}{l}\text { Thin lens of oyster eroding out of low bank c. } 5 \mathrm{~cm} \text { below ground surface } \\
\text { along c. } 4 \mathrm{~m} \text { of bank at Turkey Beach. Area to the west and south has been } \\
\text { leveled for the construction of a small toilet block and BBQ area. }\end{array}$ \\
\hline SCC58 & $\begin{array}{l}\text { Shell } \\
\text { Midden }\end{array}$ & S. Ulm & $\begin{array}{l}24^{\circ} 01^{\prime} 40^{\prime \prime} \\
151^{\circ} 44^{\prime} 40^{\prime \prime}\end{array}$ & $\begin{array}{l}\text { Surface scatter of shell on a high dune ridge up to } 50 \mathrm{~m} \text { inland on the east } \\
\text { bank of Pancake Creek immediately behind a navigation beacon opposite } \\
\text { Pancake Point. Visible shell appears to be associated with crab burrowing } \\
\text { activity and is probably derived from subsurface deposits. Oyster dominant } \\
\text { but also includes mud ark and club shell. A small silcrete core was also } \\
\text { noted. References: Ulm (1999). }\end{array}$ \\
\hline
\end{tabular}


Appendix B. Table of Site Name Synonyms for Registered Sites on the Southern Curtis Coast.

\begin{tabular}{|c|c|c|c|c|}
\hline $\begin{array}{l}\text { Registered } \\
\text { Site \# }\end{array}$ & $\begin{array}{l}\text { Burke (1993) } \\
\text { Field \# }\end{array}$ & $\begin{array}{c}\text { Burke (1993) } \\
\text { Pre-Allocated } \\
\text { Site \# }\end{array}$ & $\begin{array}{l}\text { GGCHP } \\
\text { Site ID \# }\end{array}$ & Other Designation \\
\hline KE:A05 & $\mathrm{CC} 132$ & & SCC20 & \\
\hline \multicolumn{5}{|l|}{ KE:A06 } \\
\hline $\mathrm{KE}: \mathrm{A} 08$ & & & & Boyne Creek I (Neal 1986) \\
\hline KE:A09 & & & & Boyne Creek II (Neal 1986) \\
\hline $\mathrm{KE}: \mathrm{A} 10$ & & & SCC2-SCC6 & MV1 (Rowland 1987) \\
\hline $\mathrm{KE}: \mathrm{A} 11$ & $\mathrm{CC} 144$ & & & MV2 (Rowland 1987) \\
\hline $\mathrm{KE}: \mathrm{A} 12$ & $\begin{array}{l}\mathrm{CC} 139 \\
\mathrm{CC} 043 \\
\mathrm{CC} 044 \\
\mathrm{CC} 045 \\
\mathrm{CC} 046 \\
\mathrm{CC} 047 \\
\mathrm{CC} 048 \\
\mathrm{CC} 049 \\
\mathrm{CC} 050 \\
\mathrm{CC} 051 \\
\mathrm{CC} 052\end{array}$ & $\begin{array}{l}\text { KE:A37 } \\
\text { KE:A38 } \\
\text { KE:A39 } \\
\text { KE:A40 } \\
\text { KE:A41 } \\
\text { KE:A42 } \\
\text { KE:A43 } \\
\text { KE:A44 } \\
\text { KE:A45 } \\
\text { KE:A46 }\end{array}$ & $\mathrm{SCC} 1$ & MV3 (Rowland 1987) \\
\hline KE:A16 & $\mathrm{CC} 147$ & & $\operatorname{SCC} 53$ & MV4 (Rowland 1987) \\
\hline KE:A32 & & & & Miriam Vale Homestead (Davies 1994) \\
\hline KE:A33 & $\begin{array}{l}\mathrm{CC} 141 \\
\mathrm{CC} 142 \\
\end{array}$ & $\begin{array}{l}\mathrm{KE}: \mathrm{A} 31 \\
\mathrm{KE}: \mathrm{A} 30\end{array}$ & & Tom's Creek Site Complex (Ulm 1999) \\
\hline KE:A34 & $\mathrm{CCO05}$ & KE:A32 & & \\
\hline KE:A35 & $\mathrm{CC} 006$ & KE:A33 & & Site Group 4 (Lilley 1994) \\
\hline KE:A36 & $\mathrm{CC007}$ & KE:A34 & & Site Group 4 (Lilley 1994) \\
\hline KE:A37 & $\mathrm{CC} 008$ & KE:A35 & $\mathrm{SCC} 46$ & Site Group 4 (Lilley 1994) \\
\hline $\mathrm{KE}: \mathrm{A} 38$ & $\mathrm{CC} 009$ & $\mathrm{KE}: \mathrm{A} 36$ & & \\
\hline KE:A39 & $\mathrm{CC} 065$ & $\mathrm{KE}: \mathrm{A} 47$ & & \\
\hline $\mathrm{KE}: \mathrm{A} 40$ & $\mathrm{CC} 066$ & $\mathrm{KE}: \mathrm{A} 48$ & & \\
\hline KE:A41 & $\begin{array}{l}\mathrm{CC} 067 \\
\mathrm{CC} 068\end{array}$ & $\begin{array}{l}\mathrm{KE}: \mathrm{A} 49 \\
\mathrm{KE}: \mathrm{A} 50\end{array}$ & $\mathrm{SCC} 42$ & $\begin{array}{l}\text { Rodds Peninsula Site Complex (Carter 1997) } \\
\text { Mort Creek Site Complex (Carter } \text { et al. this volume) }\end{array}$ \\
\hline $\mathrm{KE}: \mathrm{A} 42$ & $\mathrm{CC} 069$ & $\mathrm{KE}: \mathrm{A} 51$ & & \\
\hline KE:A43 & $\begin{array}{l}\mathrm{CC} 090 \\
\mathrm{CC} 091 \\
\mathrm{CC} 092 \\
\mathrm{CC} 093\end{array}$ & $\begin{array}{l}\text { KE:A52 } \\
\text { KE:A53 } \\
\text { KE:A54 } \\
\text { KE:A55 }\end{array}$ & & \\
\hline $\mathrm{KE}: \mathrm{A} 44$ & $\mathrm{CC} 094$ & $\mathrm{KE}: \mathrm{A} 56$ & $\mathrm{SCC} 45$ & Pancake Creek Site Complex (Ulm 1999) \\
\hline $\mathrm{KE}: \mathrm{A} 45$ & $\begin{array}{l}\mathrm{CC} 095 \\
\mathrm{CC} 096\end{array}$ & $\begin{array}{l}\mathrm{KE}: \mathrm{A} 57 \\
\mathrm{KE}: \mathrm{A} 58\end{array}$ & $\mathrm{SCC} 45$ & Pancake Creek Site Complex (Ulm 1999) \\
\hline $\mathrm{KE}: \mathrm{A} 46$ & $\mathrm{CC} 097$ & KE:A59 & $\mathrm{SCC} 45$ & Pancake Creek Site Complex (Ulm 1999) \\
\hline $\mathrm{KE}: \mathrm{A} 47$ & $\mathrm{CC} 098$ & KE:A60 & $\mathrm{SCC} 45$ & Pancake Creek Site Complex (Ulm 1999) \\
\hline KE:A48 & CCO99 & KE:A61 & SCC45 & Pancake Creek Site Complex (Ulm 1999) \\
\hline
\end{tabular}




\begin{tabular}{|c|c|c|c|c|}
\hline $\begin{array}{l}\text { Registered } \\
\text { Site \# }\end{array}$ & $\begin{array}{l}\text { Burke (1993) } \\
\text { Field \# }\end{array}$ & $\begin{array}{c}\text { Burke (1993) } \\
\text { Pre-Allocated } \\
\text { Site \# }\end{array}$ & $\begin{array}{l}\text { GGCHP } \\
\text { Site ID \# }\end{array}$ & Other Designation \\
\hline KE:A49 & $\begin{array}{l}\mathrm{CC} 112 \mathrm{~A} \\
\mathrm{CC} 113 \mathrm{~A} \\
\mathrm{CC} 131\end{array}$ & $\begin{array}{l}\text { KE:A62 } \\
\text { KE:A63 } \\
\text { KE:A64 }\end{array}$ & SCC43 & Eurimbula Site 1 (Ulm et al. this volume) \\
\hline $\mathrm{KE}: \mathrm{A} 50$ & $\begin{array}{l}\mathrm{CC} 114 \\
\mathrm{CC} 115 \\
\mathrm{CC} 116\end{array}$ & $\begin{array}{l}\text { KE:A65 } \\
\text { KE:A66 } \\
\text { KE:A67 }\end{array}$ & SCC43 & Eurimbula Site 1 (Ulm et al. this volume) \\
\hline $\mathrm{KE}: \mathrm{A} 51$ & $\begin{array}{l}\mathrm{CC} 117 \\
\mathrm{CC} 118\end{array}$ & $\begin{array}{l}\mathrm{KE}: \mathrm{A} 68 \\
\mathrm{KE}: \mathrm{A} 69\end{array}$ & $\mathrm{SCC} 43$ & Eurimbula Site 1 (Ulm et al. this volume) \\
\hline $\mathrm{KE}: \mathrm{A} 52$ & $\begin{array}{l}\mathrm{CC} 119 \\
\mathrm{CC} 120 \\
\mathrm{CC} 121 \\
\mathrm{CC} 122 \\
\mathrm{CC} 123 \\
\mathrm{CC} 124\end{array}$ & $\begin{array}{l}\text { KE:A70 } \\
\text { KE:A71 } \\
\text { KE:A72 } \\
\text { KE:A73 } \\
\text { KE:A74 } \\
\text { KE:A75 }\end{array}$ & $\mathrm{SCC} 43$ & Eurimbula Site 1 (Ulm et al. this volume) \\
\hline $\mathrm{KE}: \mathrm{A} 53$ & $\begin{array}{l}\mathrm{CC} 125 \\
\mathrm{CC} 126 \\
\mathrm{CC} 127\end{array}$ & $\begin{array}{l}\mathrm{KE}: A 76 \\
\mathrm{KE}: \mathrm{A77} \\
\mathrm{KE}: \mathrm{A} 78\end{array}$ & $\mathrm{SCC} 43$ & Eurimbula Site 1 (Ulm et al. this volume) \\
\hline $\mathrm{KE}: \mathrm{A} 54$ & $\begin{array}{l}\mathrm{CC} 128 \\
\mathrm{CC} 129 \\
\mathrm{CC} 130\end{array}$ & $\begin{array}{l}\text { KE:A79 } \\
\text { KE:A80 } \\
\text { KE:A81 }\end{array}$ & $\mathrm{SCC} 43$ & Eurimbula Site 1 (Ulm et al. this volume) \\
\hline KE:A55 & $\mathrm{CC} 174$ & $\mathrm{KE}: \mathrm{A} 82$ & & \\
\hline KE:A56 & $\mathrm{CC} 133$ & KE:A83 & & \\
\hline $\mathrm{KE}: \mathrm{A} 57$ & $\begin{array}{l}\mathrm{CC} 135 \\
\mathrm{CC} 136 \\
\mathrm{CC} 137\end{array}$ & $\begin{array}{l}\mathrm{KE}: A 84 \\
\mathrm{KE}: A 85 \\
\mathrm{KE}: A 86\end{array}$ & & \\
\hline KE:A58 & $\mathrm{CC} 138$ & $\mathrm{KE}: \mathrm{A} 87$ & & \\
\hline KE:A59 & $\mathrm{CC} 173$ & KE:A88 & & \\
\hline $\mathrm{KE}: \mathrm{A} 60$ & $\mathrm{CC} 148$ & $\mathrm{KE}: \mathrm{A} 89$ & $\mathrm{SCC} 52$ & \\
\hline KE:A61 & $\mathrm{CC} 169$ & KE:A90 & SCC49 & \\
\hline $\mathrm{KE}: \mathrm{A} 62$ & $\mathrm{CC} 140$ & KE:A91 & & \\
\hline $\mathrm{KE}: \mathrm{A} 63$ & $\mathrm{CC} 143$ & KE:A92 & & \\
\hline KE:A64 & & & & Site Group 1 (Lilley 1994) \\
\hline $\mathrm{KE}: \mathrm{A} 65$ & & & & Site Group 2 (Lilley 1994) \\
\hline KE:A66 & & & & Site Group 4 (Lilley 1994) \\
\hline $\mathrm{KE}: \mathrm{A} 67$ & & & $\operatorname{SCC} 47$ & $\begin{array}{l}\text { Site Group } 5 \text { (Lilley 1994) } \\
\text { Middle Island Sandblow Site (Ulm 1999) }\end{array}$ \\
\hline $\mathrm{KF}: \mathrm{A} 01$ & $\mathrm{CC} 064$ & KF:A01 & & \\
\hline $\mathrm{KF}: \mathrm{A02}$ & $\begin{array}{l}\mathrm{CC} 071 \\
\mathrm{CC} 072 \\
\mathrm{CC} 073 \\
\mathrm{CC} 074\end{array}$ & $\begin{array}{l}\text { KF:A02 } \\
\text { KF:A03 } \\
\text { KF:A04 } \\
\text { KF:A05 }\end{array}$ & & \\
\hline $\mathrm{KF}: \mathrm{A03}$ & $\begin{array}{l}\mathrm{CC} 075 \\
\mathrm{CC} 076\end{array}$ & $\begin{array}{l}\mathrm{KF}: \mathrm{A} 06 \\
\mathrm{KF}: \mathrm{A} 07\end{array}$ & & \\
\hline KF:A04 & $\mathrm{CC} 077$ & KF:A08 & & \\
\hline
\end{tabular}




\begin{tabular}{|c|c|c|c|c|}
\hline $\begin{array}{l}\text { Registered } \\
\text { Site \# }\end{array}$ & $\begin{array}{l}\text { Burke (1993) } \\
\text { Field \# }\end{array}$ & $\begin{array}{l}\text { Burke (1993) } \\
\text { Pre-Allocated } \\
\text { Site \# }\end{array}$ & $\begin{array}{l}\text { GGCHP } \\
\text { Site ID \# }\end{array}$ & Other Designation \\
\hline KF:A05 & $\begin{array}{l}\mathrm{CC} 078 \\
\mathrm{CC} 080\end{array}$ & $\begin{array}{l}\text { KF:A09 } \\
\text { KF:A10 }\end{array}$ & & \\
\hline KF:A06 & $\begin{array}{l}\mathrm{CC} 081 \\
\mathrm{CC} 082\end{array}$ & $\begin{array}{l}\text { KF:A11 } \\
\text { KF:A12 }\end{array}$ & & \\
\hline KF:A07 & $\begin{array}{l}\mathrm{CC} 087 \\
\mathrm{CC} 088\end{array}$ & $\begin{array}{l}\mathrm{KF}: \mathrm{A} 13 \\
\mathrm{KF}: \mathrm{A} 14\end{array}$ & & \\
\hline KF:A08 & $\mathrm{CC} 101$ & KF:A15 & & \\
\hline KF:A09 & $\mathrm{CC} 102$ & KF:A16 & & \\
\hline KF:A10 & $\mathrm{CC} 103$ & KF:A17 & & \\
\hline KF:A11 & $\begin{array}{l}\mathrm{CC} 104 \\
\mathrm{CC} 105\end{array}$ & $\begin{array}{l}\mathrm{KF}: \mathrm{A} 18 \\
\mathrm{KF}: \mathrm{A} 19\end{array}$ & & \\
\hline KF:A12 & $\mathrm{CC} 100$ & KF:A20 & SCC54 & \\
\hline KF:A13 & $\begin{array}{l}\mathrm{CC} 070 \\
\mathrm{CC} 083\end{array}$ & $\begin{array}{l}\text { KF:A21 } \\
\text { KF:A22 }\end{array}$ & & \\
\hline KF:A14 & $\begin{array}{l}\mathrm{CC} 084 \\
\mathrm{CC} 085\end{array}$ & $\begin{array}{l}\text { KF:A23 } \\
\text { KF:A24 }\end{array}$ & & \\
\hline KF:A15 & $\mathrm{CC} 086$ & KF:A25 & & \\
\hline \multirow[t]{20}{*}{ KF:A16 } & $\mathrm{CC} 089$ & KF:A26 & & \\
\hline & & & $\mathrm{SCC} 10$ & \\
\hline & & & $\mathrm{SCC} 12$ & \\
\hline & & & $\mathrm{SCC} 17$ & \\
\hline & & & SCC18 & \\
\hline & & & SCC19 & \\
\hline & & & SCC21 & \\
\hline & & & $\mathrm{SCC} 26$ & $\begin{array}{l}\text { SCC26-SCC29, SCC41 (Lilley et al. 1997) } \\
\text { Ironbark Site Complex (Reid 1998) }\end{array}$ \\
\hline & & & $\operatorname{sCC} 30$ & \\
\hline & & & SCC31 & \\
\hline & & & $\operatorname{SCC} 35$ & \\
\hline & & & SCC36 & \\
\hline & & & SCC37 & Eurimbula Creek 1 (Ulm 1999) \\
\hline & & & $\mathrm{SCC} 38$ & Eurimbula Creek 2 (Ulm 1999) \\
\hline & & & $\operatorname{SCC} 39$ & \\
\hline & & & $\mathrm{SCC} 48$ & \\
\hline & & & sCC50 & \\
\hline & & & SCC51 & \\
\hline & & & $\operatorname{scc55}$ & \\
\hline & & & $\operatorname{scC} 58$ & \\
\hline
\end{tabular}


Appendix C. Radiocarbon Dates from Excavated Sites on the Southern Curtis Coast.

\begin{tabular}{|c|c|c|c|c|c|c|c|c|c|c|c|c|}
\hline Site & Square & $\mathbf{X U}$ & $\begin{array}{c}\text { Depth } \\
(\mathbf{c m})\end{array}$ & Lab. No. & Sample & $\begin{array}{c}\text { Weight } \\
\text { (g) }\end{array}$ & $\begin{array}{l}d^{14} \mathrm{C} \\
(\% o)\end{array}$ & $\begin{array}{l}\delta^{13} \mathrm{C} \\
(\%)\end{array}$ & $\begin{array}{l}\mathbf{D}^{14} \mathrm{C} \\
(\% o)\end{array}$ & \% Modern & ${ }^{14} \mathrm{C}$ Age & Calibrated Age/s $\mathbf{s}^{\mathrm{e}}$ \\
\hline Eurimbula Site 1 & 1 & 5 & 9.5 & Wk-5601 & charcoal & 2.5 & $-30.8 \pm 7.6$ & $-27.0 \pm 0.2$ & $-26.9 \pm 9.3$ & $97.3 \pm 0.9$ & $220 \pm 80$ & $430\left(272,178,149,9,0^{*}\right) 0^{*}$ \\
\hline Eurimbula Site 1 & 1 & 10 & 35 & Wk-3944 & shell $^{\mathrm{a}}$ & 71.1 & $-219.8 \pm 4.5$ & $-0.8 \pm 0.2$ & $-257.6 \pm 5.2$ & $74.2 \pm 0.5$ & $2390 \pm 60$ & $2170(1997) 1842$ \\
\hline Eurimbula Site 1 & 1 & 10 & 35 & Wk-5215 & charcoal & 2.1 & $-181.3 \pm 12.7$ & $-25.3 \pm 0.2$ & $-180.8 \pm 15.5$ & $81.9 \pm 1.5$ & $1600 \pm 160$ & $1821(1412) 1167$ \\
\hline Eurimbula Site 1 & 2 & 9 & 50 & Wk-3945 & charcoal & 10.3 & $-315.3 \pm 4.4$ & $-26.5 \pm 0.2$ & $-313.3 \pm 5.3$ & $68.7 \pm 0.5$ & $3020 \pm 70$ & $3352(3200,3197,3154) 2943$ \\
\hline Eurimbula Site 1 & Near 7 & 0 & 0 & Wk-3946 & shell $^{\mathrm{a}}$ & 90.7 & $-17.7 \pm 4.8$ & $0.0 \pm 0.2$ & $-66.8 \pm 5.6$ & $93.3 \pm 0.6$ & $560 \pm 50$ & $300(234) 0^{*}$ \\
\hline $\mathrm{MCSC}$ & A7 & 4 & $18-20.2$ & Wk-5602 & shell $^{\mathrm{a}}$ & 47.3 & $-264.7 \pm 3.7$ & $-0.3 \pm 0.2$ & $-301.0 \pm 4.3$ & $69.9 \pm 0.4$ & $2880 \pm 50$ & $2755(2692) 2450$ \\
\hline MCSC & A7 & 6 & $22.6-26.7$ & Wk-3937 & shell ${ }^{a}$ & 75.2 & $-269.3 \pm 4.0$ & $0.1 \pm 0.2$ & $-305.9 \pm 4.7$ & $69.4 \pm 0.5$ & $2930 \pm 60$ & $2826(2718) 2494$ \\
\hline MCSC & $\mathrm{A} 7$ & 9 & $32.4-37$ & Wk-3938 & shel. $]^{\mathrm{a}}$ & 81.2 & $-249.3 \pm 4.3$ & $0.1 \pm 0.2$ & $-286.9 \pm 5.0$ & $71.3 \pm 0.5$ & $2720 \pm 60$ & $2681(2370) 2283$ \\
\hline MCSC & Granite & $11 \mathrm{M}$ & $45.5-52.1$ & Wk-3941 & shell ${ }^{\mathrm{a}}$ & 71.3 & $-246.4 \pm 4.5$ & $-0.2 \pm 0.2$ & $-283.8 \pm 5.3$ & $71.6 \pm 0.5$ & $2680 \pm 60$ & $2598(2339) 2188$ \\
\hline $\mathrm{MCSC}$ & Granite & $11 \mathrm{C}$ & $45.5-52.1$ & Wk-3940 & shell $^{\mathrm{b}}$ & 66.7 & $-296.9 \pm 4.4$ & $0.7 \pm 0.2$ & $-333.1 \pm 5.1$ & $66.7 \pm 0.5$ & $3260 \pm 70$ & $3304(3075) 2865$ \\
\hline MCSC & WP & 4 & $12.8-18.4$ & Wk-3942 & shell" & 79.6 & $-222.3 \pm 5.7$ & $0.6 \pm 0.2$ & $-262.2 \pm 6.6$ & $73.8 \pm 0.7$ & $2440 \pm 80$ & $2307(2071) 1861$ \\
\hline MCSC & WP & 10 & $37.6-44.8$ & Wk-3943 & shell ${ }^{a}$ & 74.8 & $-235.9 \pm 4.4$ & $-0.5 \pm 0.2$ & $-273.4 \pm 5.1$ & $72.7 \pm 0.5$ & $2570 \pm 60$ & $2358(2273) 2057$ \\
\hline
\end{tabular}

a Anadara trapezia

b

Mixed shell consisting of Saccostrea, Polynices, Nerita chamaeleon, Placamen calophyllum, Fragum hemicardium, Gafrarium australe, Cymatium sp., Corbula sp., Antigona chemnitzii, Trisidos tortuosa, Tapes dorsatus, Meropesta sp., Pinctada sp., Trichomya hirsuta, Bembicium auratum, Calthalotia arruensis and Anadara trapezia.

c

Conventional ${ }^{14} \mathrm{C}$ ages are corrected for ${ }^{13} \mathrm{C}^{\prime 2} \mathrm{C}$ fractionation and were calibrated using the CALIB (v3.0.3c) computer program (Stuiver and Reimer 1993). Determinations based on charcoal samples were calibrated using the bi-decal atmospheric calibration curve using the datasets of Pearson and Stuiver (1993) and Stuiver and Pearson (1993) with no laboratory error multiplier. Forty years were subtracted before calibration to correct for ${ }^{14} \mathrm{C}$ variations between northern and southern hemispheres. Dates on marine shell samples were calibrated using the marine calibration dataset of Stuiver and Braziunas (1993) with a $\Delta \mathrm{R}$ correction value of $-5 \pm 35$. The calibrated ages reported span the $2 \sigma$ calibrated age-range.

0* Represents a 'negative' or 'modern' age BP. 